\title{
TOPK inhibition accelerates oxidative stress-induced granulosa cell apoptosis via the p53/SIRT1 axis
}

\author{
JUNG-HWAN PARK ${ }^{1}$, SANG-AH PARK ${ }^{1}$, YOUNG-JU LEE ${ }^{1}$, \\ NA-RAE JOO ${ }^{1}$, JONGDAE SHIN ${ }^{2}$ and SANG-MUK OH ${ }^{1,3}$
}

\begin{abstract}
Departments of ${ }^{1}$ Biochemistry and ${ }^{2}$ Cell Biology, College of Medicine, Konyang University; ${ }^{3}$ Priority Research Center, Myunggok Medical Research Institute, College of Medicine, Konyang University, Daejeon 35365, Republic of Korea
\end{abstract}

Received February 20, 2020; Accepted July 29, 2020

DOI: $10.3892 / \mathrm{ijmm} .2020 .4712$

\begin{abstract}
It has been suggested that oxidative stress involving reactive oxygen species (ROS) induces granulosa cell apoptosis, leading to follicular atresia, and that T-lymphokine-activated killer cell-originated protein kinase (TOPK) suppresses cancer cell apoptosis induced by several stimuli. However, it remains to be determined whether TOPK affects oxidative stress-induced granulosa cell apoptosis. The present study demonstrates that TOPK inhibition increases human granulosa COV434 cell apoptosis induced by hydrogen peroxide $\left(\mathrm{H}_{2} \mathrm{O}_{2}\right)$. Co-treatment with the TOPK inhibitor, OTS514, in combination with $\mathrm{H}_{2} \mathrm{O}_{2}$ increased p53 acetylation and its expression, whereas it decreased Sirtuin 1 (SIRT1) expression, contributing to the promotion of apoptosis. In addition, the SIRT1 activator, resveratrol, or the SIRT1 inhibitor, Ex527, reduced or elevated $\mathrm{H}_{2} \mathrm{O}_{2}$-induced COV434 cell apoptosis, respectively. Furthermore, the p53 inhibitor, Pifithrin- $\mu$, diminished the augmentation in poly(ADP-ribose) polymerase (PARP) cleavage induced by OTS514 plus $\mathrm{H}_{2} \mathrm{O}_{2}$, while the Mdm2 antagonist, Nutlin 3, increased PARP cleavage. Moreover, OTS514 further decreased the SIRT1 transcriptional activity decreased by $\mathrm{H}_{2} \mathrm{O}_{2}$, but promoted the $\mathrm{H}_{2} \mathrm{O}_{2}$-induced p53 or p21 transcriptional activity. Notably, the expression of exogenous p53 reduced SIRT1 transcriptional activity. Taken together, the findings of the present study demonstrate that TOPK inhibition promotes p53-mediated granulosa cell apoptosis through
\end{abstract}

Correspondence to: Dr Sang-Muk Oh, Department of Biochemistry, College of Medicine, Konyang University, 158 Gwanjeodong-ro, Seo-gu, Daejeon 35365, Republic of Korea E-mail: sangmuk_oh@konyang.ac.kr

Abbreviations: TOPK, T-lymphokine-activated killer cell-originated protein kinase; SIRT1, sirtuin1; ROS, reactive oxygen species; $\mathrm{H}_{2} \mathrm{O}_{2}$, hydrogen peroxide; PARP, poly(ADP-ribose) polymerase; HDAC, histone deacetylase; MnSOD, manganese superoxide dismutase; Bax, Bcl-2-associated X protein

Key words: T-lymphokine-activated killer cell-originated protein kinase, apoptosis, granulosa cell, p53, Sirtuin 1
SIRT1 downregulation in response to $\mathrm{H}_{2} \mathrm{O}_{2}$. Therefore, it can be concluded that TOPK suppresses $\mathrm{H}_{2} \mathrm{O}_{2}$-induced apoptosis through the modulation of the p53/SIRT1 axis, suggesting a potential role of TOPK in the regulation of human granulosa cell apoptosis, leading to the promotion of abnormal follicular development.

\section{Introduction}

The ovaries are known to be unique and crucial female organs which reproduce generations of eggs and secrete sex hormones for the female secondary sexual characteristics. However, the number of ovarian follicles secreted during a lifetime is limited. Follicles consist of several cells, including oocytes, granulosa cells and theca cells. The oocyte is surrounded by layers of granulosa cells and forms a direct connection with granulosa cells. It has been suggested that granulosa cells not only provide nutrient to oocytes, but also protect oocytes from oxidative stress during follicle development $(1,2)$, and that reactive oxygen species (ROS)-mediated oxidative stress results in granulosa cell apoptosis to promote abnormal follicular development (3).

It has been reported that sirtuin 1 (SIRT1), a well-known $\mathrm{NAD}^{+}$dependent deacetylase (class III histone deacetylase), influences not only histone proteins, but also non-histone proteins, and regulates various biological processes involving aging, apoptosis or the stress response $(4,5)$. In addition, SIRT1 is known to induce the phosphorylation of extracellular signal-regulated kinase (ERK) and inhibit the translocation of nuclear factor (NF)- $\kappa \mathrm{B}$ into the nucleus, leading to suppression of granulosa cell apoptosis (6). It has been shown that various microRNAs (miRNAs or miRs) such as miRNA-590-3P or miRNA-494 suppress SIRT1 activity to promote apoptosis $(7,8)$. It has been suggested that SIRT1 deacetylates lysine 382 of p53, thereby reducing p53 transcriptional activity and p53-mediated apoptosis, whereas p53 expression suppresses the transcription of SIRT1 gene induced by c-Myc (9-11).

T-LAK cell originated protein kinase (TOPK), a type of serine/threonine kinase, has been shown to be strongly expressed in various solid cancers, including colorectal cancer (12-14), lung cancer $(15,16)$, gastric cancer $(17)$, prostate cancer $(18,19)$, ovarian carcinoma $(20)$, nasopharyngeal 
carcinoma (21) and esophageal squamous cell carcinoma (22). TOPK consists of 322 amino acids and has a functional similarity with MKK3/6, which activates p38 $(23,24)$. However, it has been reported that TOPK phosphorylates ERK in EGF-stimulated HCT116 colorectal cancer cells or T47D cells $(25,26)$ and phosphorylates JNK1 in ras-induced cell transformation or UVB-mediated signaling (27). In addition, TOPK has been shown to contribute to an increased metastasis of breast cancer cells by modulating the expression of MMP9 through the regulation of NF- $\kappa \mathrm{B}$ activity in LPS signaling (28). On the other hand, it has been reported that TOPK directly binds to the DNA-binding domain of p53 and suppresses p53 transcriptional activity $(29,30)$. However, whether TOPK affects oxidative stress-induced granulosa cell apoptosis remains to be determined.

In the present study, it was first revealed that TOPK inhibition increased p53-mediated granulosa cell apoptosis through SIRT1 downregulation upon $\mathrm{H}_{2} \mathrm{O}_{2}$ treatment. It was demonstrated that p53 negatively regulated SIRT1 transcriptional activity in response to $\mathrm{H}_{2} \mathrm{O}_{2}$, which was aggravated by TOPK inhibition. It was also found that TOPK inhibition promoted p53 stability, leading to an increase in $\mathrm{H}_{2} \mathrm{O}_{2}$-induced granulosa cell apoptosis. These findings provide evidence that TOPK suppresses $\mathrm{H}_{2} \mathrm{O}_{2}$-induced granulosa cell apoptosis through the regulation of the p53/SIRT1 axis.

\section{Materials and methods}

Cell culture and reagents. Human granulosa COV434 cells were purchased from Sigma-Aldrich; Merck KGaA. HeLa cells were purchased from the American Type Culture Collection (ATCC) and maintained in DMEM supplemented with $10 \%$ FBS, 2 mM L-glutamine, and 1\% penicillin and streptomycin (Thermo Fisher Scientific, Inc.). COV434 cells were maintained in high glucose Dulbecco's modified Eagle's medium (DMEM) supplemented with $10 \%$ fetal bovine serum, $2 \mathrm{mM}$ L-glutamine, $1 \%$ penicillin and streptomycin at $37^{\circ} \mathrm{C}$ in a $\mathrm{CO}_{2}$ incubator with $5 \% \mathrm{CO}_{2}$. Rabbit anti-TOPK (ab75987), rabbit anti-SIRT1 (ab32441), mouse anti-p53 (ab26), rabbit anti-phospho-p53 (Ser-15) (ab1431) and rabbit anti-acetyl p53 (K382) (ab75754) antibodies were purchased from Abcam. Rabbit anti-cleaved poly(ADP-ribose) polymerase (PARP) antibody (\#9541) was purchased from Cell Signaling Technology, Inc. Mouse anti- $\beta$-actin antibody (A1975) was purchased from Sigma-Aldrich. OTS514, Z-VAD-FMK were purchased from Selleckchem; 2',7'-dichloroflurescin diacetate, Nutlin-3, Pifithrin- $\mu$, resveratrol and Ex527 were purchased Sigma-Aldrich; Merck KGaA. Annexin V-FITC antibody and propidium iodide were purchased from Thermo Fisher Scientific, Inc. The luciferase assay kit was purchased from Promega Corporation.

Plasmids and transfection. The SIRT1 promoter linked luciferase reporter gene, SIRT1-Luc construct was generated. Briefly, an approximately $1 \mathrm{~kb}$ promoter region containing nucleotides -1 to $-1,026$ of the human SIRT1 gene was amplified using the Takara Ex Taq polymerase (Takara Bio, Inc.) and human genomic DNA (Promega Corporation) as a template. The amplified product was cloned into the NheI and XhoI sites of the pGL3-basic vector (cat. no. E1751, Promega
Corporation). The specific primer sequences were as follows: Forward, 5'-CCGGCTAACCCATACTAGGCTTAAGG-3' and reverse, 5'-CCGCTCGAGCTTCCAACTGCCTCTCTG GC-3'. p53-GFP was a gift from Geoff Wahl (Addgene plasmid \#11770). The pGL2-p53 promoter-Luc construct was a gift from Wafik El-Deiry (Addgene plasmid \#16292) and the pGL2-p21 promoter-Luc plasmid was a gift from Martin Walsh (addgene plasmid \#33021). The pcDNA3.1 or pEGFP-N1 vector was purchased from Invitrogen; Thermo Fisher Scientific, Inc. (cat. no. V79020) or Clontech (cat. no. 6085-1), respectively, and the V5-TOPK construct was previously described (31). Briefly, total RNA from HeLa cells was prepared, and cDNA synthesis and PCR were performed using Superscript III reverse transcriptase (Invitrogen; Thermo Fisher Scientific, Inc.) and primers, 5'-CGCGGATCCCGATGGAAGGGATCAGTAATTT-3' harboring the BamHI site (forward) and 5'-CGCTCGAGC GGGACATCTGTTTCCAGAGCTT-3' harboring the XhoI site (reverse). The PCR product digested with $B a m \mathrm{HI} / \mathrm{XhoI}$ was inserted into the $\mathrm{BamHI} / \mathrm{XhoI}$ sites of pcDNA6/V5-His ABC (cat. no. V22020, Invitrogen; Thermo Fisher Scientific, Inc.), generating the V5-TOPK construct. Non-target siRNA and p53 siRNA were purchased from Dharmacon. COV434 cells growing in 12-well plates were transfected with $1 \mu \mathrm{g}$ of pcDNA3.1 or V5-TOPK, $2 \mu \mathrm{g}$ of pGL3-SIRT1 promoter-Luc, $1 \mu \mathrm{g}$ of pEGFP-N1, pGL2-p53 promoter-Luc or pGL2-p21 promoter-Luc plasmids or $30 \mathrm{nM}$ of non-target or p53 siRNA using Lipofectamine 3000 (Invitrogen; Thermo Fisher Scientific, Inc.) according to manufacturer's instructions. At $24 \mathrm{~h}$ following transfection, cells were lysed, and luciferase assay was performed using cell lysate.

Flow cytometric analysis. A total of $1 \times 10^{6}$ of COV434 cells growing on $60 \mathrm{~mm}$ dishes were pre-treated with inhibitors or activators, OTS514 $(20 \mathrm{nM})$, Z-VAD-FMK $(50 \mu \mathrm{M})$, resveratrol $(20 \mu \mathrm{M})$, Ex527 (30 nM), Pifithrin- $\mu(1 \mu \mathrm{M})$, or Nutlin-3 $(10 \mu \mathrm{M})$ for $2 \mathrm{~h}$ and $\mathrm{H}_{2} \mathrm{O}_{2}(0.1 \mathrm{mM})$ was then added for $24 \mathrm{~h}$. Apoptosis analysis was performed using Annexin V-FITC and propidium iodide according to manufacturer's instructions (Thermo Fisher Scientific, Inc.), and data were acquired using a FACScalibur (BD Biosciences).

2',7'-Dichloroflurescin diacetate assay. COV434 cells growing on $60 \mathrm{~mm}$ dishes at $80 \%$ confluency were pre-treated with OTS514 (20 nM) for $2 \mathrm{~h}$, and incubated at $37^{\circ} \mathrm{C}$ with $\mathrm{H}_{2} \mathrm{O}_{2}$ $(0.1 \mathrm{mM})$ for $24 \mathrm{~h}$. The conditioned medium was removed, and fresh medium containing $10 \mu \mathrm{M} \mathrm{H} 2 \mathrm{DCF}-\mathrm{DA}$ was added. The cells were then incubated at $37^{\circ} \mathrm{C}$ for $30 \mathrm{~min}$, and then washed and trypsinized. Cells were resuspended using conditioned medium. DCF fluorescence was measured using a FACScalibur (BD Biosciences).

TUNEL assay. A total of $2 \times 10^{6}$ of COV434 cells were seeded in 6-well plates and pre-treated with inhibitor or activator, OTS514 (20 nM), Z-VAD-FMK $(50 \mu \mathrm{M})$, resveratrol $(20 \mu \mathrm{M})$, Ex527 (30 nM), Pifithrin- $\mu(1 \mu \mathrm{M})$, or Nutlin-3 $(10 \mu \mathrm{M})$, for $2 \mathrm{~h}$, and then $\mathrm{H}_{2} \mathrm{O}_{2}(0.1 \mathrm{mM})$ was added for $24 \mathrm{~h}$. Apoptosis was determined using the DeadEnd ${ }^{\mathrm{TM}}$ Fluorometric TUNEL System (G3250, Promega Corporation). The cells were fixed using $4 \%$ formaldehyde for $25 \mathrm{~min}$ at $4^{\circ} \mathrm{C}$, and then permeabilized by $0.2 \%$ Triton $\mathrm{X}-100$ for $5 \mathrm{~min}$ at room temperature. The 
cells were labeled using $50 \mu \mathrm{l}$ of TdT reaction mix and incubated for $60 \mathrm{~min}$ at $37^{\circ} \mathrm{C}$ and then data analysis was performed using a laser-scanning confocal microscope Zeiss LSM 710 (Zeiss AG).

Western blot analysis. Briefly, cells were harvested and lysed using lysis buffer containing $0.5 \%$ Triton X-100, 1 mM EDTA, $50 \mathrm{mM}$ Tris- $\mathrm{HCl}, \mathrm{pH} 7.4$ and $40 \mathrm{mM} \mathrm{NaCl}$. Briefly, $30 \mu \mathrm{g}$ of cell lysate was separated on 8 or $10 \%$ SDS-PAGE and transferred to nitrocellulose membranes (Bio-Rad Laboratories, Inc.). The membranes were blocked with $5 \%$ skim milk in Tris-buffered saline and Tween-20 (TBST) for $1 \mathrm{~h}$ and then

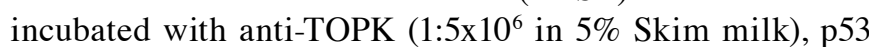
(1:1,000 in TBST), phospho-p53 (1:1,000 in TBST), acetyl-p53 (1:1,000 in 5\% Skim milk), cleaved PARP (1:1,000 in TBST), SIRT1 (1:1,000 in TBST) and $\beta$-actin (1: 20,000 in 5\% Skim milk) antibodies at $4^{\circ} \mathrm{C}$ for overnight. The membranes were washed 3 times for 5 min using TBST, and then incubated at room temperature with goat anti-rabbi IgG, polyclonal (1:4,000 in 5\% Skim milk, ADI-SAB-300-J, Enzo Life Sciences) or goat anti-Mouse polyclonal (1:4,000 in 5\% Skim milk, ADI-SAB-100-J, Enzo Life Sciences) antibodies for $2 \mathrm{~h}$. After washing, the blots were analyzed with SuperSignal West Pico chemiluminescent substrate (Pierce; Thermo Fisher Scientific, Inc.) and X-ray film. Each protein level was determined using Image J software (ver.1.52a; National Institute of Health).

Luciferase assay. A total of $1 \times 10^{5}$ of COV434 cells were seeded in 12-well plates. After $24 \mathrm{~h}, 1 \mu \mathrm{g}$ of SIRT1, p53 or $\mathrm{p} 21$ promoter-luciferase reporter constructs plus $0.5 \mu \mathrm{g}$ of the $p R L-S V 40$ gene were transfected into the COV434 cells using Lipofectamine 3000 reagent. At $24 \mathrm{~h}$ following transfection, the cells were pre-treated with OTS514 (20 nM), resveratrol $(20 \mu \mathrm{M})$, Ex527 (30 nM), Pifithrin- $\mu(1 \mu \mathrm{M})$ or Nutlin-3 $(10 \mu \mathrm{M})$ for $2 \mathrm{~h}$, and then incubated at $37^{\circ} \mathrm{C}$ with $0.1 \mathrm{mM} \mathrm{H}_{2} \mathrm{O}_{2}$ for $24 \mathrm{~h}$. Cells were harvested and lysed. Firefly and Renilla luciferase activities were measured using Dual-Luciferase ${ }^{\circledR}$ Reporter assay system (E1910, Promega Corporation).

Protein stability assay. COV434 cells were seeded in 6-well plates. After $24 \mathrm{~h}$, the cells were pre-treated with OTS514 $(20 \mathrm{nM})$ for $2 \mathrm{~h}$, and then treated with $\mathrm{H}_{2} \mathrm{O}_{2}(0.1 \mathrm{mM})$ for $24 \mathrm{~h}$ at $37^{\circ} \mathrm{C} .24 \mathrm{~h}$ after $\mathrm{H}_{2} \mathrm{O}_{2}$ treatment, cells were incubated with cycloheximide (10 $\mu \mathrm{g} / \mathrm{ml})$ (Sigma-Aldrich) for 0,2 , or $8 \mathrm{~h}$, and then were harvested, lysed and subjected to western blot analysis.

Statistical analysis. Results are presented as the means \pm standard deviation (SD) for at least 3 independent experiments in duplicate. Statistical analysis was carried out by one-way ANOVA with Tukey's test or two-way ANOVA followed by Bonferroni's correction. P-values $<0.05$ were considered to indicate statistically significant differences.

\section{Results}

TOPK inhibition increases $\mathrm{H}_{2} \mathrm{O}_{2}$-induced human COV434 granulosa cell apoptosis. Previous studies have demonstrated that oxidative stress induces granulosa cell apoptosis and SIRT1 downregulation mediated by oxidative stress contributes to this apoptosis (32-34). In addition, it has been suggested that TOPK functions as a survival effector in several cancer cells (35-37). Based on these findings, the present study wished to determine whether TOPK inhibition affects $\mathrm{H}_{2} \mathrm{O}_{2}$-induced granulosa cell apoptosis or SIRT1 expression. COV434 cells were treated with $\mathrm{H}_{2} \mathrm{O}_{2}$, OTS514 or $\mathrm{H}_{2} \mathrm{O}_{2}$ plus OTS514 for $24 \mathrm{~h}$. Treatment of human COV434 granulosa cells with the TOPK inhibitor, OTS514, increased the number of TUNEL-positive cells induced by $\mathrm{H}_{2} \mathrm{O}_{2}$ stimulation (Fig. 1A), and significantly elevated the $\mathrm{H}_{2} \mathrm{O}_{2}$-induced cleavage of PARP (Fig. 1B). Of note, OTS514 treatment dose-dependently decreased TOPK expression upregulated by $\mathrm{H}_{2} \mathrm{O}_{2}$ and abolished the expression of SIRT1 downregulated by $\mathrm{H}_{2} \mathrm{O}_{2}$. Furthermore, the total p53 level, as well as its phosphorylation and acetylation were markedly increased upon $\mathrm{H}_{2} \mathrm{O}_{2}$ stimulation, and these effects were enhanced by OTS514 co-treatment. These data suggest that TOPK plays an important role in the regulation of p53 or SIRT1 expression in response to $\mathrm{H}_{2} \mathrm{O}_{2}$.

Subsequently, the effects of TOPK overexpression on the cleavage of PARP induced by $\mathrm{H}_{2} \mathrm{O}_{2}$ were examined. For this purpose, the COV434 cells were transfected with empty vector or TOPK overexpression vector for $24 \mathrm{~h}$, and then incubated with a combination of $\mathrm{H}_{2} \mathrm{O}_{2}$ or OTS514 for $24 \mathrm{~h}$. TOPK overexpression blocked the $\mathrm{H}_{2} \mathrm{O}_{2}$-induced cleavage of PARP (Fig. 1C). Furthermore, the effects of TOPK inhibition on endogenous ROS generation were investigated by 2',7'-dichloroflurescin diacetate assay. The results revealed that targeting TOPK by OTS514 treatment enhanced the $\mathrm{H}_{2} \mathrm{O}_{2}$-induced ROS generation in granulosa cells, accelerating $\mathrm{H}_{2} \mathrm{O}_{2}$-induced the apoptosis (Fig. 1D).

Caspase inhibitor blocks granulosa cell apoptosis induced by co-treatment with $\mathrm{H}_{2} \mathrm{O}_{2}$ and OTS514. The present study then examined whether granulosa cell apoptosis induced by $\mathrm{H}_{2} \mathrm{O}_{2}$ and OTS514 is dependent on caspase-dependent apoptotic signaling pathways. COV434 cells were exposed to $\mathrm{H}_{2} \mathrm{O}_{2}$ only, $\mathrm{H}_{2} \mathrm{O}_{2}$ plus OTS514 or $\mathrm{H}_{2} \mathrm{O}_{2}$ plus OTS514 in combination with Z-VAD-FMK for $24 \mathrm{~h}$. Co-treatment of the COV434 cells with OTS514 and $\mathrm{H}_{2} \mathrm{O}_{2}$ markedly increased the number of TUNEL-positive cells, compared to the cells stimulated with $\mathrm{H}_{2} \mathrm{O}_{2}$ only. However, co-treatment with the cell-permeable, irreversible pan-caspase inhibitor, Z-VAD-FMK, significantly decreased the number of TUNEL-positive cells (Fig. 2A). Consistent with this finding, flow cytometric analysis indicated that Z-VAD-FMK effectively diminished the number of Annexin V-positive cells induced by treatment with $\mathrm{H}_{2} \mathrm{O}_{2}$ and OTS514 (Fig. 2B). These findings suggest that caspase-dependent apoptosis pathways play a pivotal role in granulosa cell apoptosis induced by $\mathrm{H}_{2} \mathrm{O}_{2}$ and OTS514.

SIRT1 plays an important role in the regulation of $\mathrm{H}_{2} \mathrm{O}_{2}$-induced granulosa cell apoptosis. Subsequently, whether SIRT1 regulates $\mathrm{H}_{2} \mathrm{O}_{2}$-induced granulosa cell apoptosis was investigated. For this purpose, the SIRT1 activator, resveratrol, or the SIRT1 inhibitor, Ex527, were employed. The COV434 cells were incubated with $\mathrm{H}_{2} \mathrm{O}_{2}$ only, or $\mathrm{H}_{2} \mathrm{O}_{2}$ plus resveratrol or Ex527. As was expected, co-treatment with resveratrol decreased $\mathrm{H}_{2} \mathrm{O}_{2}$-induced apoptosis (Fig. 3A), whereas co-treatment with Ex527 increased apoptosis. In addition, western blot analysis revealed that co-treatment with resveratrol decreased 


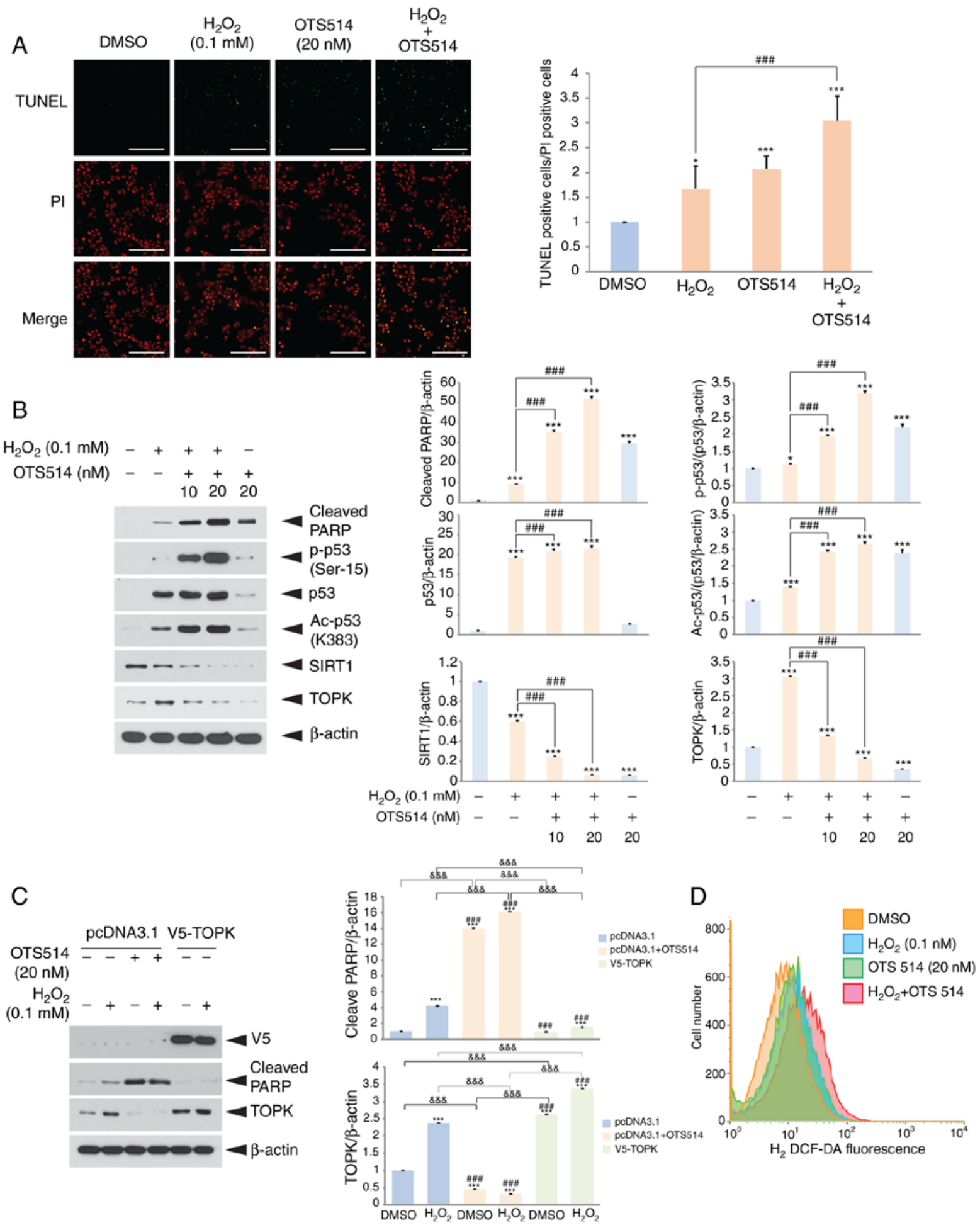

Figure 1. TOPK inhibition aggravates $\mathrm{H}_{2} \mathrm{O}_{2}$-induced human COV434 granuolsa cell apoptosis and decreases the endogenous SIRT1 level. (A) COV434 cells were treated with DMSO, $\mathrm{H}_{2} \mathrm{O}_{2}$, OTS514 or $\mathrm{H}_{2} \mathrm{O}_{2}$ plus OTS514 for $24 \mathrm{~h}$, fixed and then examined for apoptosis by TUNEL assay. Cells were treated with OTS514 for $2 \mathrm{~h}$ prior to $\mathrm{H}_{2} \mathrm{O}_{2}$ exposure. Nuclei were stained with propidium iodide (PI). The ratio of TUNEL-positive cells to PI-positive cells is shown. Scale bar, $100 \mu \mathrm{m}$. (B) COV434 cells were treated with DMSO (-), $\mathrm{H}_{2} \mathrm{O}_{2}$ or $\mathrm{H}_{2} \mathrm{O}_{2}$ plus OTS514 for $24 \mathrm{~h}$. Cell lysates were separated on SDS-PAGE, and then subjected to western blot analysis using indicated antibodies. The $\beta$-actin level was used as a loading control. (C) COV434 cells were transfected with empty vector, pcDNA3.1 or TOPK overexpression vector, V5-TOPK for $24 \mathrm{~h}$, and then treated with a combination of $\mathrm{H}_{2} \mathrm{O}_{2}$ or OTS514 for $24 \mathrm{~h}$. Western blot analysis was performed using indicated antibodies. (D) COV434 cells were incubated with DMSO, $\mathrm{H}_{2} \mathrm{O}_{2}$ or $\mathrm{H}_{2} \mathrm{O}_{2}$ in combination with OTS514 for $24 \mathrm{~h}$. $\mathrm{H} 2 \mathrm{DCF}-\mathrm{DA}(10 \mu \mathrm{M})$ was added and incubated for $30 \mathrm{~min}$. DCF fluorescence was measured by flow cytometry. Representative images of 3 independent experiments and graphs for quantitation are shown. ${ }^{*} \mathrm{P}<0.05,{ }^{* * *} \mathrm{P}<0.001$ vs. DMSO. ${ }^{\# \# "} \mathrm{P}<0.001$ vs. $\mathrm{H}_{2} \mathrm{O}_{2}$ or $\mathrm{H}_{2} \mathrm{O}_{2}$ control. \&\&\& $\mathrm{P}<0.001$ (two-way ANOVA with Bonferroni's correction).

the level of cleaved PARP level, as well as the acetylated p53 level induced by $\mathrm{H}_{2} \mathrm{O}_{2}$ (Fig. 3B); however, co-treatment with Ex527 increased the level of cleaved PARP and acetylated p53 level (Fig. 3C). These findings demonstrate that SIRT1 activity affects $\mathrm{H}_{2} \mathrm{O}_{2}$-induced granulosa cell apoptosis and they p53 level or activity is a key factor for the suppression of apoptosis. 

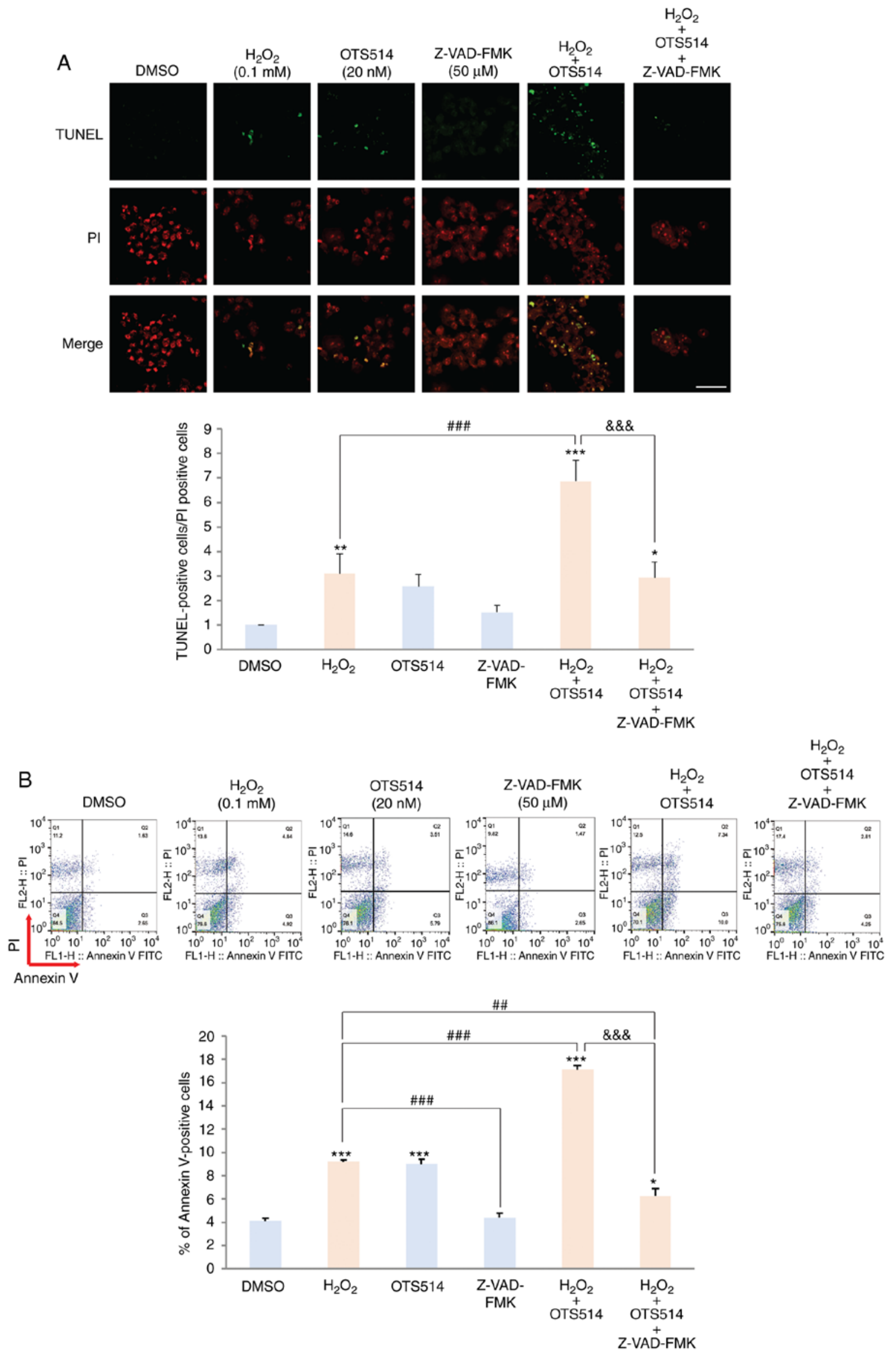

Figure 2. Caspase inhibition disrupts granulosa cell apoptosis induced by $\mathrm{H}_{2} \mathrm{O}_{2}$ and OTS514. COV434 cells were treated with DMSO, $\mathrm{H}_{2} \mathrm{O}_{2}, \mathrm{OTS} 514_{\text {plus }} \mathrm{H}_{2} \mathrm{O}_{2}$ or OTS514 plus $\mathrm{H}_{2} \mathrm{O}_{2}$ in combination with Z-VAD-FMK for $24 \mathrm{~h}$, fixed, and then apoptosis was estimated by (A) TUNEL assay or (B) flow cytometry. Ratio of (A) TUNEL-positive cells to PI-positive cells or (B) \% of Annexin V positive cells is shown. Scale bar, $50 \mu$ m. Representatives of 3 independent experiments are indicated. ${ }^{*} \mathrm{P}<0.05,{ }^{* * *} \mathrm{P}<0.01,{ }^{* * *} \mathrm{P}<0.001$ vs. DMSO. ${ }^{\# \#} \mathrm{P}<0.01,{ }^{\# \# \#} \mathrm{P}<0.001$ vs. $\mathrm{H}_{2} \mathrm{O}_{2}$. ${ }^{\text {\&\&\& }} \mathrm{P}<0.001$ vs. $\mathrm{H}_{2} \mathrm{O}_{2}+\mathrm{OTS} 514$ 

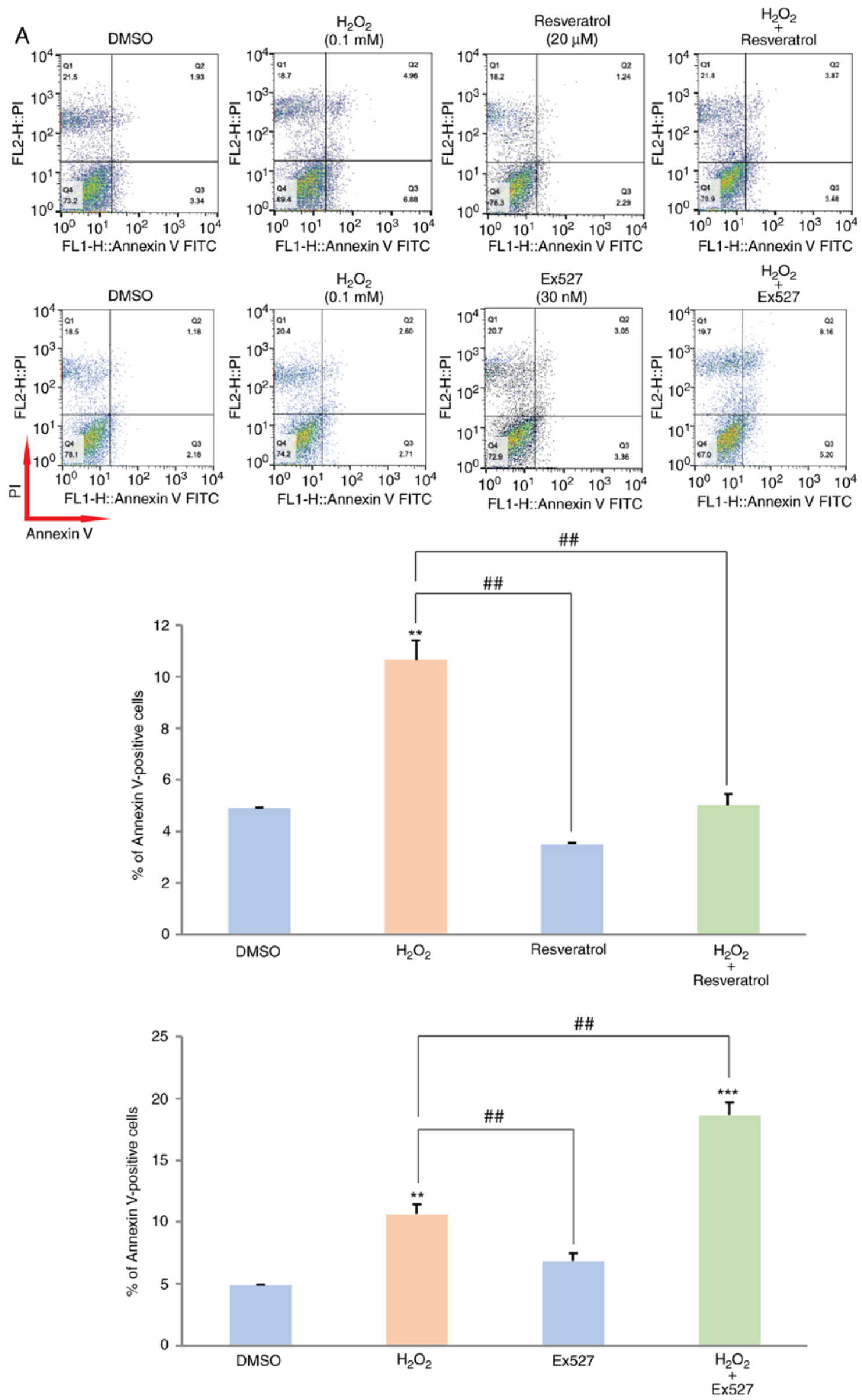

Figure 3. SIRT1 activity affects $\mathrm{H}_{2} \mathrm{O}_{2}$-induced granulosa cell apoptosis. (A) COV434 cells were incubated with a combination of $\mathrm{H}_{2} \mathrm{O}_{2}$ and resveratrol or Ex527 for $24 \mathrm{~h}$. Apoptosis was analyzed by flow cytometry. The \% of Annexin V-positive cells is indicated. 


\section{B}

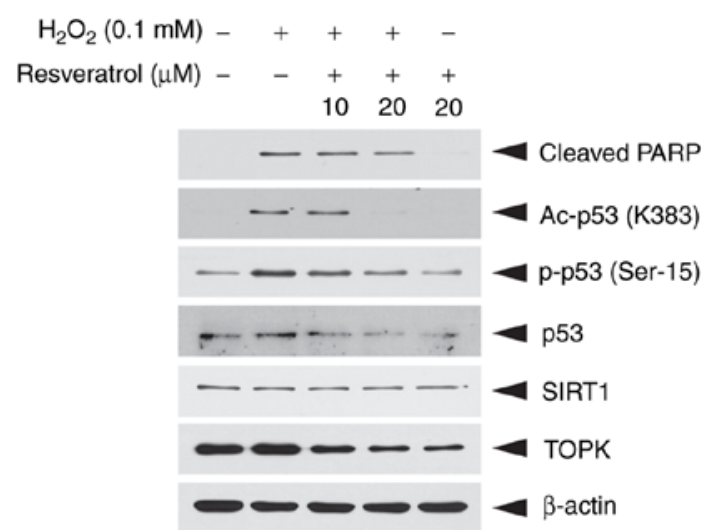

C
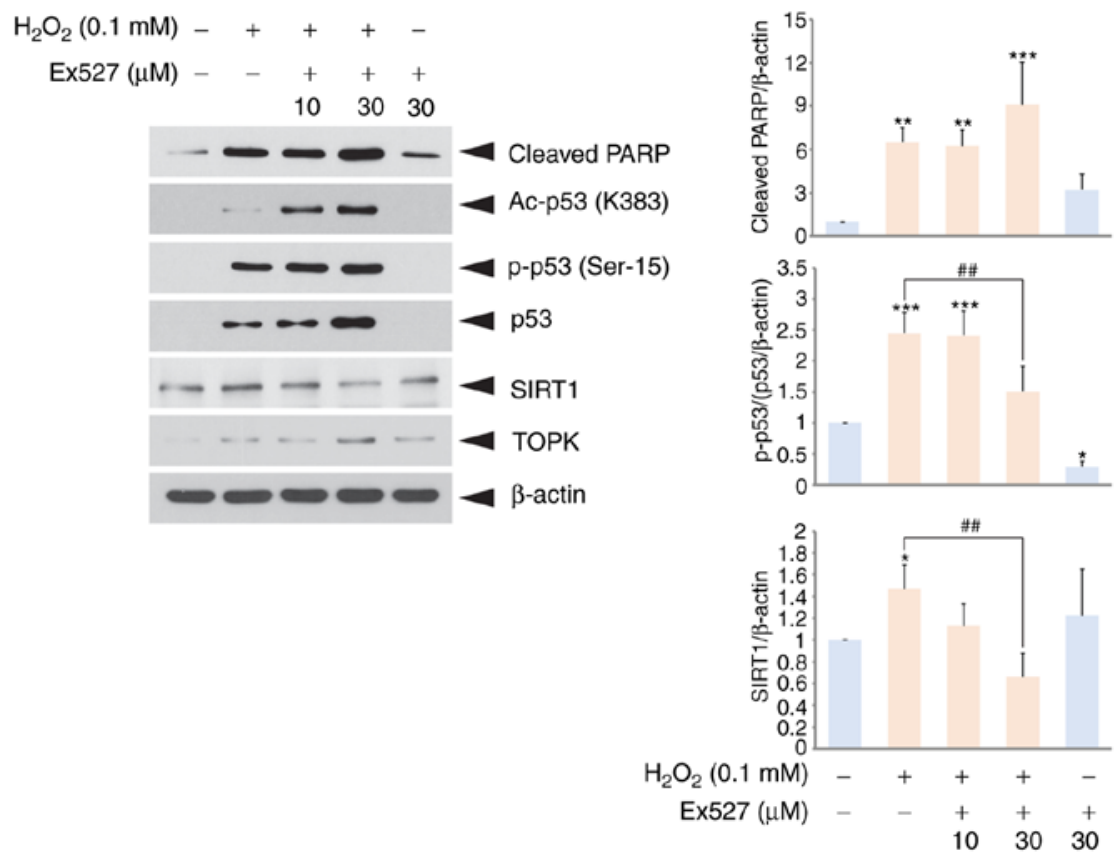
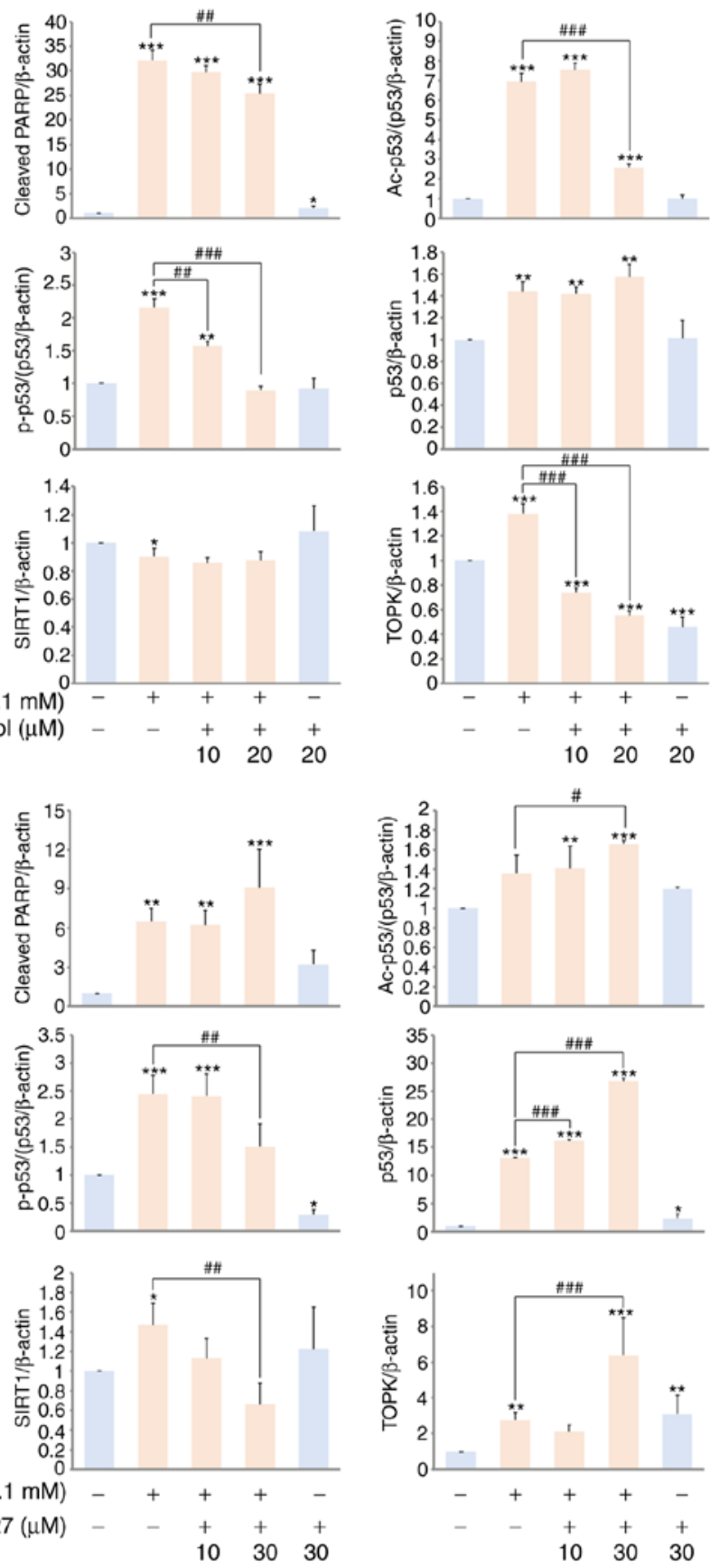

Figure 3. Continued. SIRT1 activity affects $\mathrm{H}_{2} \mathrm{O}_{2}$-induced granulosa cell apoptosis. (B and C) COV434 cells were treated with $\mathrm{DMSO}_{2} \mathrm{H}_{2} \mathrm{O}_{2}$ only, $\mathrm{H}_{2} \mathrm{O}_{2}$ plus Ex527 or resveratrol for $24 \mathrm{~h}$. Cells were lysed and then subjected to western blot analysis using indicated antibodies. Graphs for quantification are indicated Representatives of 3 independent experiments are shown. ${ }^{*} \mathrm{P}<0.05,{ }^{* *} \mathrm{P}<0.01,{ }^{* * * *} \mathrm{P}<0.001$ vs. DMSO. ${ }^{\#} \mathrm{P}<0.05,{ }^{\# \#} \mathrm{P}<0.01,{ }^{\# \# \#} \mathrm{P}<0.001$ vs. $\mathrm{H}_{2} \mathrm{O}_{2}$.

p53 inhibition suppresses $\mathrm{H}_{2} \mathrm{O}_{2}$ or OTS514-induced granulosa cell apoptosis. It has been suggested that tumor suppressor $\mathrm{p} 53$ is involved in granulosa cell apoptosis in response to oxidative stress or cAMP-mediated signaling $(33,38)$. The present study then wished to determine whether p53 affects COV434 cell apoptosis upon $\mathrm{H}_{2} \mathrm{O}_{2}$ and OTS514 treatment. For this purpose, COV434 cells were treated with a combination of $\mathrm{H}_{2} \mathrm{O}_{2}$, OTS514 or the p53 inhibitor, Pifithrin- $\mu$. The inhibition of p53 by Pifithrin- $\mu$ treatment decreased the $\mathrm{H}_{2} \mathrm{O}_{2}$-induced increase in the level of cleaved PARP (Fig. 4A). Co-treatment with OTS514 decreased TOPK expression, elevated the p53 level and decreased SIRT1 expression. In addition, TUNEL assay revealed that the inhibition of p53 decreased the $\mathrm{H}_{2} \mathrm{O}_{2}$-induced
COV434 cell apoptosis by approximately 2-fold. However, co-treatment with OTS514 increased cell apoptosis (Fig. 4B). Taken together, these results demonstrate that p53 plays a key role in $\mathrm{H}_{2} \mathrm{O}_{2}$ or OTS514-induced granulosa cell apoptosis.

Inhibition of $\mathrm{Mdm} 2$ accelerates $\mathrm{H}_{2} \mathrm{O}_{2}$ - and OTS514-induced granulosa cell apoptosis. To examine the effects of Mdm2 inhibition on $\mathrm{H}_{2} \mathrm{O}_{2}$ and OTS514-induced granulosa cell apoptosis, the Mdm2 antagonist, Nutlin 3, that inhibits the interaction of Mdm2 and p53 was employed. Treatment of the COV434 cells with Nutlin 3 elevated the levels of cleaved PARP, total p53, acetylated p53 or the phosphorylated p53 level, whereas it decreased the SIRT1 level upon $\mathrm{H}_{2} \mathrm{O}_{2}$ and OTS514 

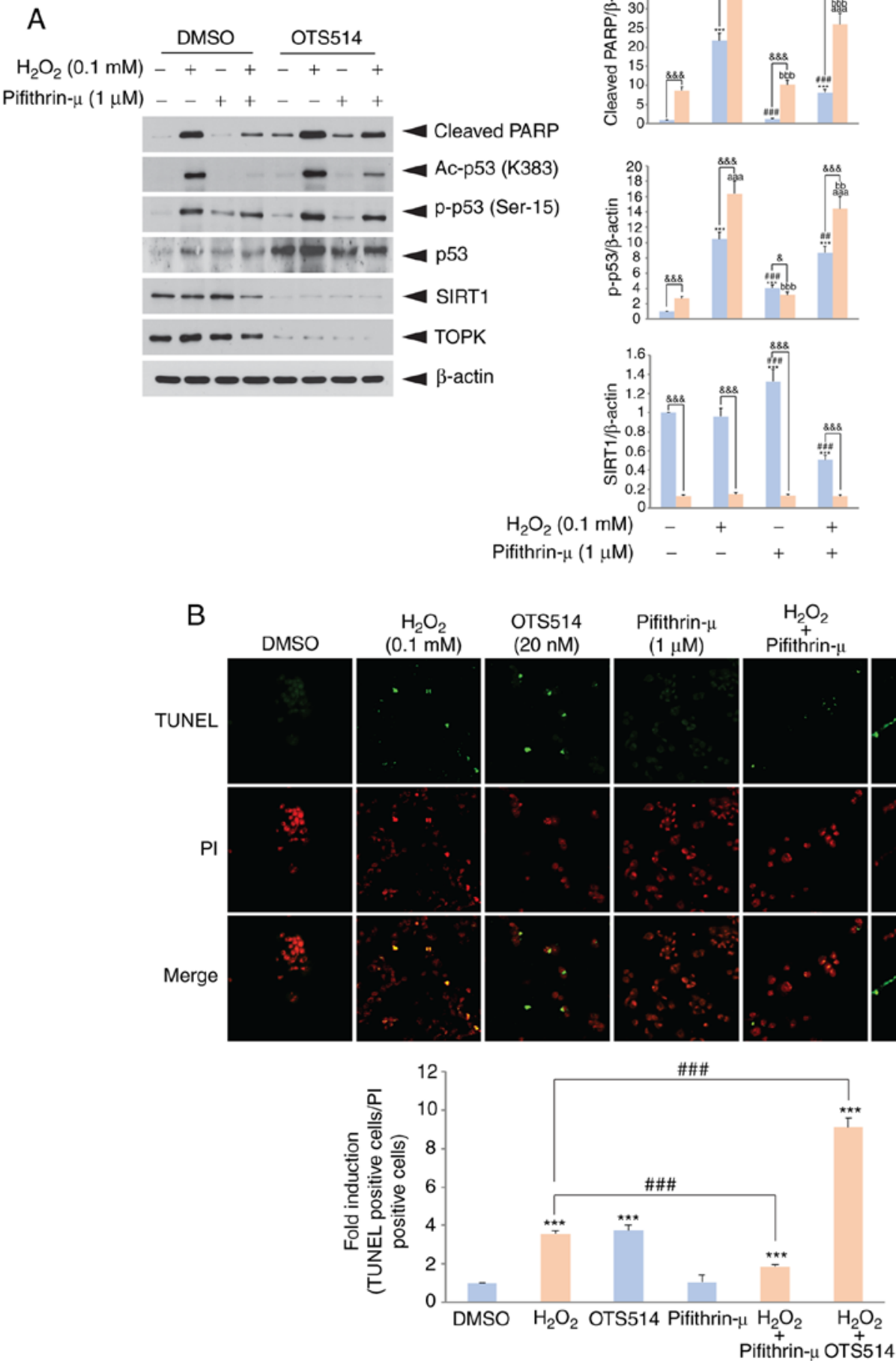

Pifithrin- $\mu(1 \mu \mathrm{M})$
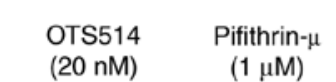

$\mathrm{H}_{2} \mathrm{O}_{2}$
+
Pifithrin-
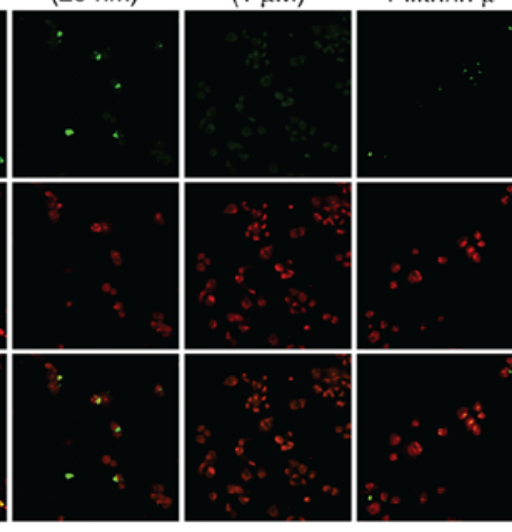
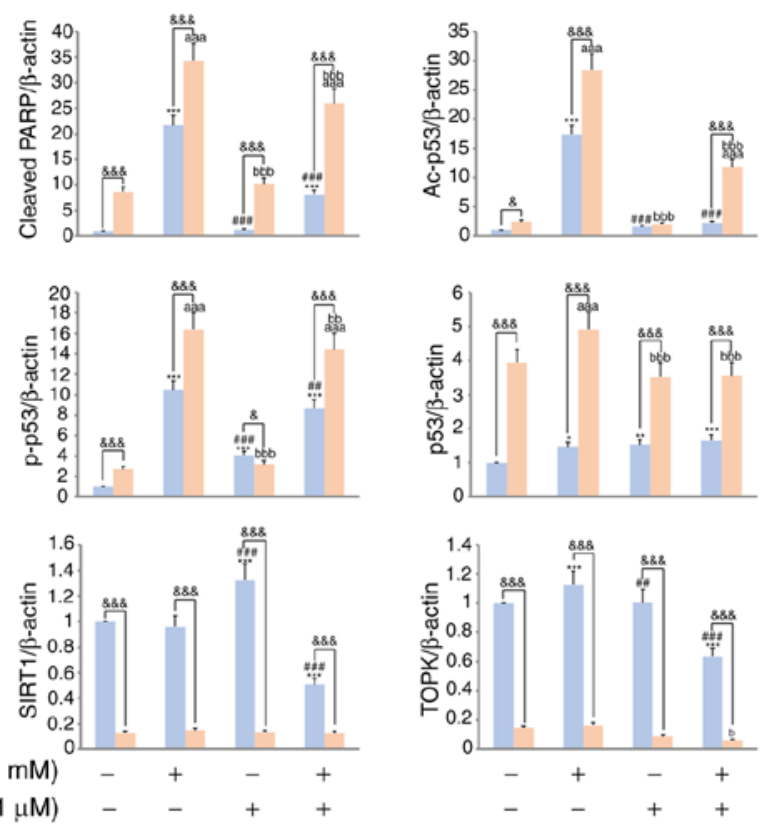

$\mathrm{H}_{2} \mathrm{O}_{2}$

OTS 514

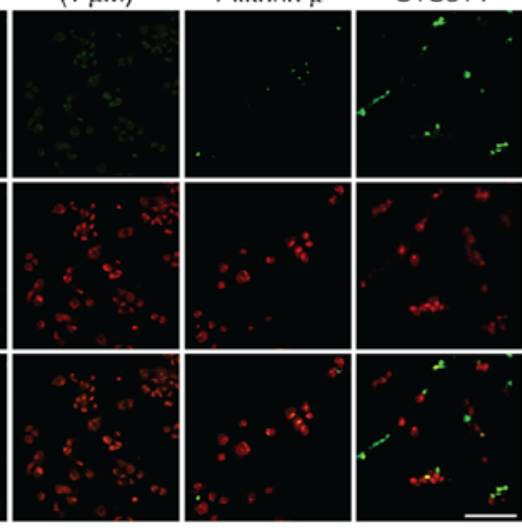

Figure 4. p53 inhibition alleviates granulosa cell apoptosis induced by $\mathrm{H}_{2} \mathrm{O}_{2}$ or OTS514. (A) COV434 cells were treated with a combination of $\mathrm{H}_{2} \mathrm{O}_{2}$ and OTS514 or Pifithrin- $\mu$ for $24 \mathrm{~h}$. Cells were lysed and then subjected to SDS-PAGE and western blot analysis using indicated antibodies. Graphs for quantification are shown. (B) COV434 cells were incubated with a combination of $\mathrm{H}_{2} \mathrm{O}_{2}$ with Pifithrin- $\mu$ or OTS514 for 24 h. Cells were fixed, and apoptosis was analyzed by TUNEL assay. Ratio of TUNEL-positive cells to PI-positive cells is shown. Scale bar, $100 \mu$ m. Representatives of 3 independent experiments are indicated. ${ }^{*} \mathrm{P}<0.05,{ }^{* *} \mathrm{P}<0.01,{ }^{* * * *} \mathrm{P}<0.001$ vs. DMSO. ${ }^{\# \#} \mathrm{P}<0.01,{ }^{\# \# \#} \mathrm{P}<0.001$ vs. $\mathrm{H}_{2} \mathrm{O}_{2} .{ }^{\text {aaa }} \mathrm{P}<0.001$ vs. OTS514. ${ }^{\text {b }} \mathrm{P}<0.05,{ }^{\text {bb }} \mathrm{P}<0.01,{ }^{\text {bbb }} \mathrm{P}<0.001$ vs. OTS514 $+\mathrm{H} \mathrm{O}_{2} .{ }^{\star} \mathrm{P}<0.05$, \&\&\& $\mathrm{P}<0.001$ (two-way ANOVA with Bonferroni's correction).

treatment (Fig. 5A). Moreover, flow cytometric analysis indicated that the inhibition of the interaction of Mdm2 and p53 markedly increased the number of Annexin V-positive cells (Fig. 5B). Subsequently, whether p53 knockdown affects the $\mathrm{H}_{2} \mathrm{O}_{2}$-induced decrease in SIRT1 expression was examined. As was expected, the results revealed that p53 knockdown markedly restored SIRT1 expression to decrease the $\mathrm{H}_{2} \mathrm{O}_{2}$-induced cleavage of PARP (Fig. 5C). These findings suggest that both the level and activity of p53 may function as important factors in the regulation of granulosa cell apoptosis. 
A
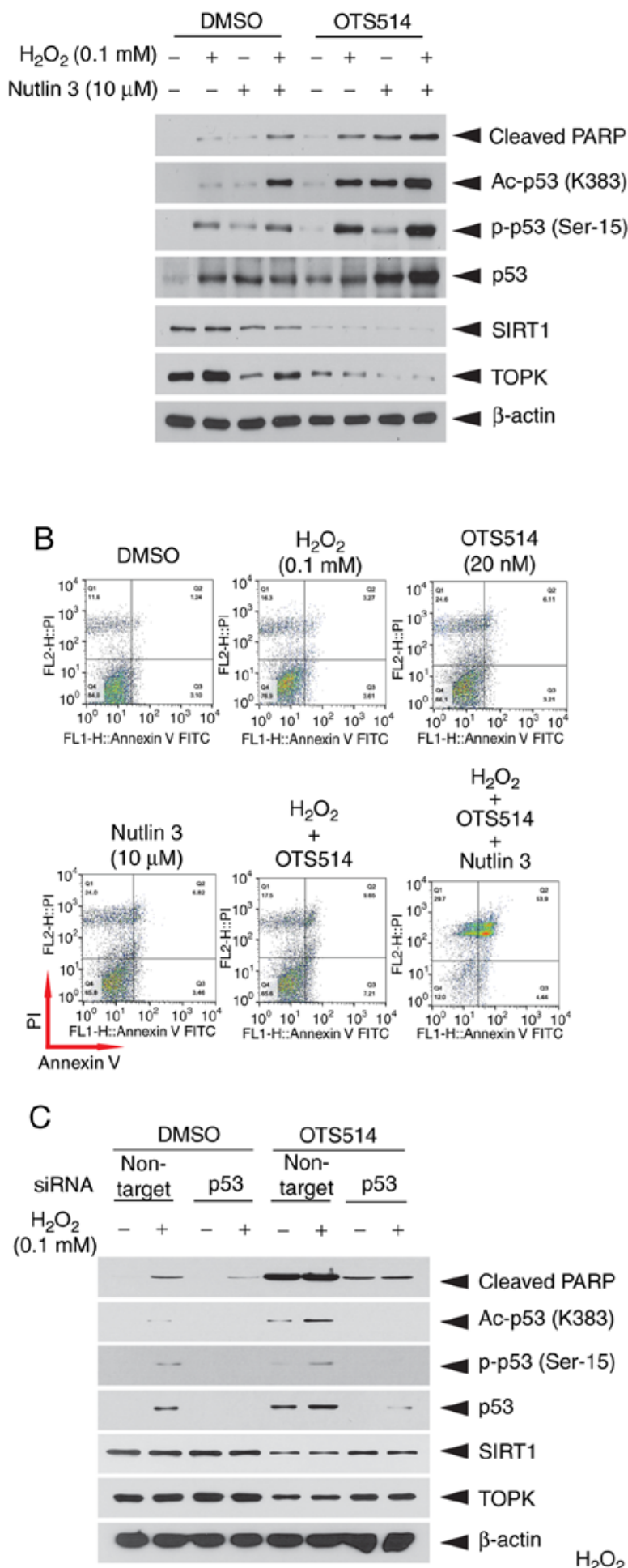
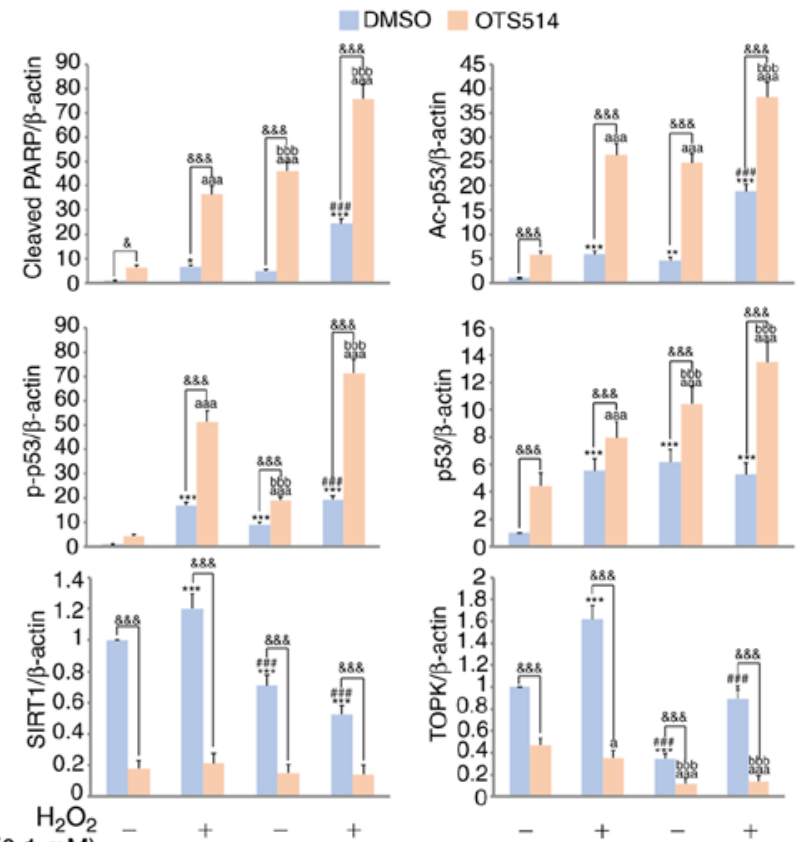

$(0.1 \mathrm{mM})$

Nutlin 3

$(10 \mu \mathrm{M})$
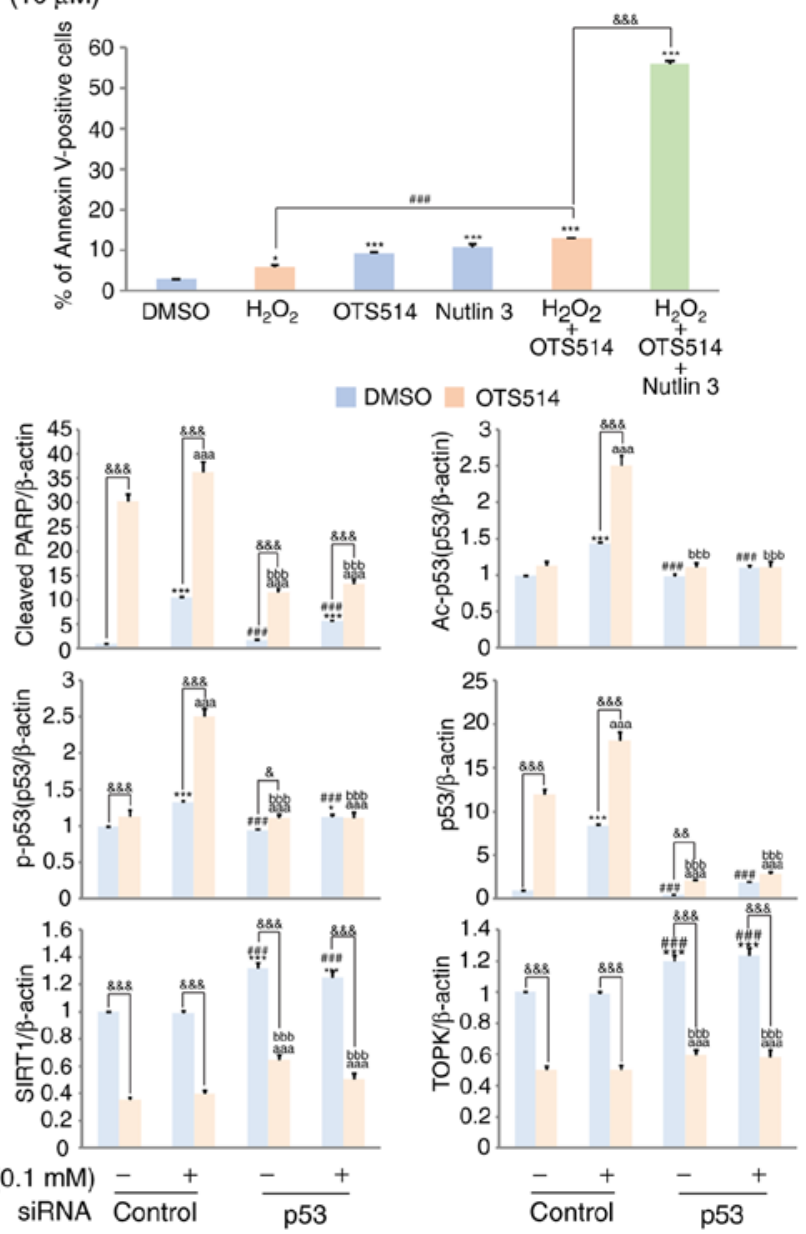

Figure 5. Mdm2 antagonist markedly accelerates the p53 level or granulosa cell apoptosis induced by $\mathrm{H}_{2} \mathrm{O}_{2}$ or OTS514. (A) COV434 cells were incubated in combination of $\mathrm{H}_{2} \mathrm{O}_{2}$ with OTS514 or nutlin 3 for $24 \mathrm{~h}$. Cells lysates were subjected to western blot analysis using indicated antibodies. Graphs for quantitation are indicated. ${ }^{*} \mathrm{P}<0.05,{ }^{* *} \mathrm{P}<0.01,{ }^{* * * *} \mathrm{P}<0.001$ vs. DMSO. ${ }^{\# \# \#} \mathrm{P}<0.001$ vs. $\mathrm{H}_{2} \mathrm{O}_{2} .{ }^{a} \mathrm{P}<0.05,{ }^{\text {aaa }} \mathrm{P}<0.001$ vs. OTS514 control. ${ }^{\text {bbb }} \mathrm{P}<0.001$ vs. $\mathrm{H}_{2} \mathrm{O}_{2}+\mathrm{OTS} 514$. ${ }^{\& \& \&} \mathrm{P}<0.001$ (two-way ANOVA with Bonferroni's correction). (B) COV434 cells were treated with a combination of $\mathrm{H}_{2} \mathrm{O}_{2}$ with $\mathrm{OTS} 14$ or nutlin 3 for 24 h. Apoptosis was estimated using flow cytometry. The \% of Annexin V-positive cells is shown. Representative images of 3 independent experiments are shown. ${ }^{*} \mathrm{P}<0.05,{ }^{* * *} \mathrm{P}<0.001$ vs. DMSO. ${ }^{\# \# \#} \mathrm{P}<0.001$ vs. $\mathrm{H}_{2} \mathrm{O}_{2}$. ${ }^{\& \&} \mathrm{P}<0.001$ vs. $\mathrm{H}_{2} \mathrm{O}_{2}+\mathrm{OTS} 514$. (C) COV434 cells were transfected with non-target siRNA or p53 siRNA for $48 \mathrm{~h}$, and then treated with a combination of $\mathrm{H}_{2} \mathrm{O}_{2}$ with OTS514 for $24 \mathrm{~h}$. Western blot analysis was performed using indicated antibodies. Graphs for quantification are indicated. ${ }^{*} \mathrm{P}<0.05,{ }^{* * *} \mathrm{P}<0.001$ vs. DMSO. ${ }^{\# \# \#} \mathrm{P}<0.001$ vs. $\mathrm{H}_{2} \mathrm{O}_{2}$. ${ }^{\text {aaa }} \mathrm{P}<0.001$ vs. OTS514 control. ${ }^{\text {bbb }} \mathrm{P}<0.001$ vs. $\mathrm{H}_{2} \mathrm{O}_{2}+\mathrm{OTS} 514$. ${ }^{\&} \mathrm{P}<0.05$, ${ }^{\&} \mathrm{P}<0.01,{ }^{\& \&} \mathrm{P}<0.001$ (two-way ANOVA with Bonferroni's correction). 


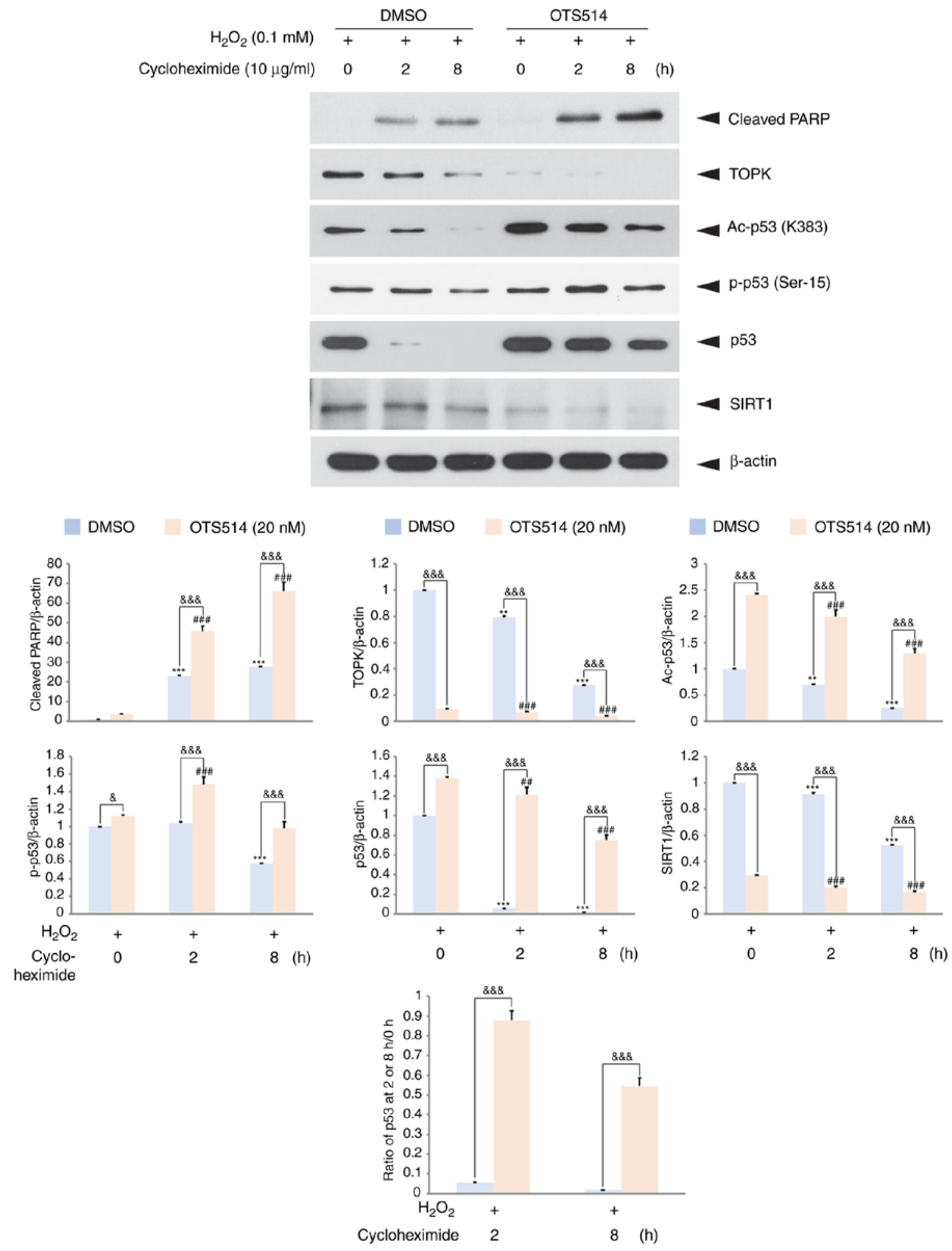

Figure 6. TOPK inhibition positively regulates p53 stability. COV434 cells were treated with OTS514 for 2 h prior to $\mathrm{H}_{2} \mathrm{O}_{2}$ treatment. At 24 h following $\mathrm{H}_{2} \mathrm{O}_{2}$ treatment, cells were incubated with cycloheximide for the indicated periods of time. Western blot analysis was performed using indicated antibodies. Graphs for quantification are shown. Representatives of 3 independent experiments are indicated. ${ }^{* *} \mathrm{P}<0.01,{ }^{* * * *} \mathrm{P}<0.001$ vs. DMSO. ${ }^{\# \#} \mathrm{P}<0.01,{ }^{\# \# \#} \mathrm{P}<0.001$ vs. $\mathrm{H}_{2} \mathrm{O}_{2}$. ${ }^{\&} \mathrm{P}<0.05,{ }^{\& \& \&} \mathrm{P}<0.001$ (two-way ANOVA with Bonferroni's correction).

To examine whether p53 stability is affected by TOPK inhibition in $\mathrm{H}_{2} \mathrm{O}_{2}$-exposed granulosa cells, a cycloheximide chase experiment was then performed. The COV434 cells were treated with $\mathrm{H}_{2} \mathrm{O}_{2}$, OTS514 and cycloheximide, an inhibitor of protein biosynthesis. The level of acetylated p53, as well as the total p53 or cleaved PARP level in the
$\mathrm{H}_{2} \mathrm{O}_{2}$ - and OTS514-treated cells was elevated, while the TOPK or SIRT1 level was almost abolished $8 \mathrm{~h}$ following cycloheximide treatment compared with the cells stimulated with $\mathrm{H}_{2} \mathrm{O}_{2}$ only (Fig. 6). These findings suggest that TOPK inhibitor positively regulates p53 stability in $\mathrm{H}_{2} \mathrm{O}_{2}$-stimulated granulosa cells. 


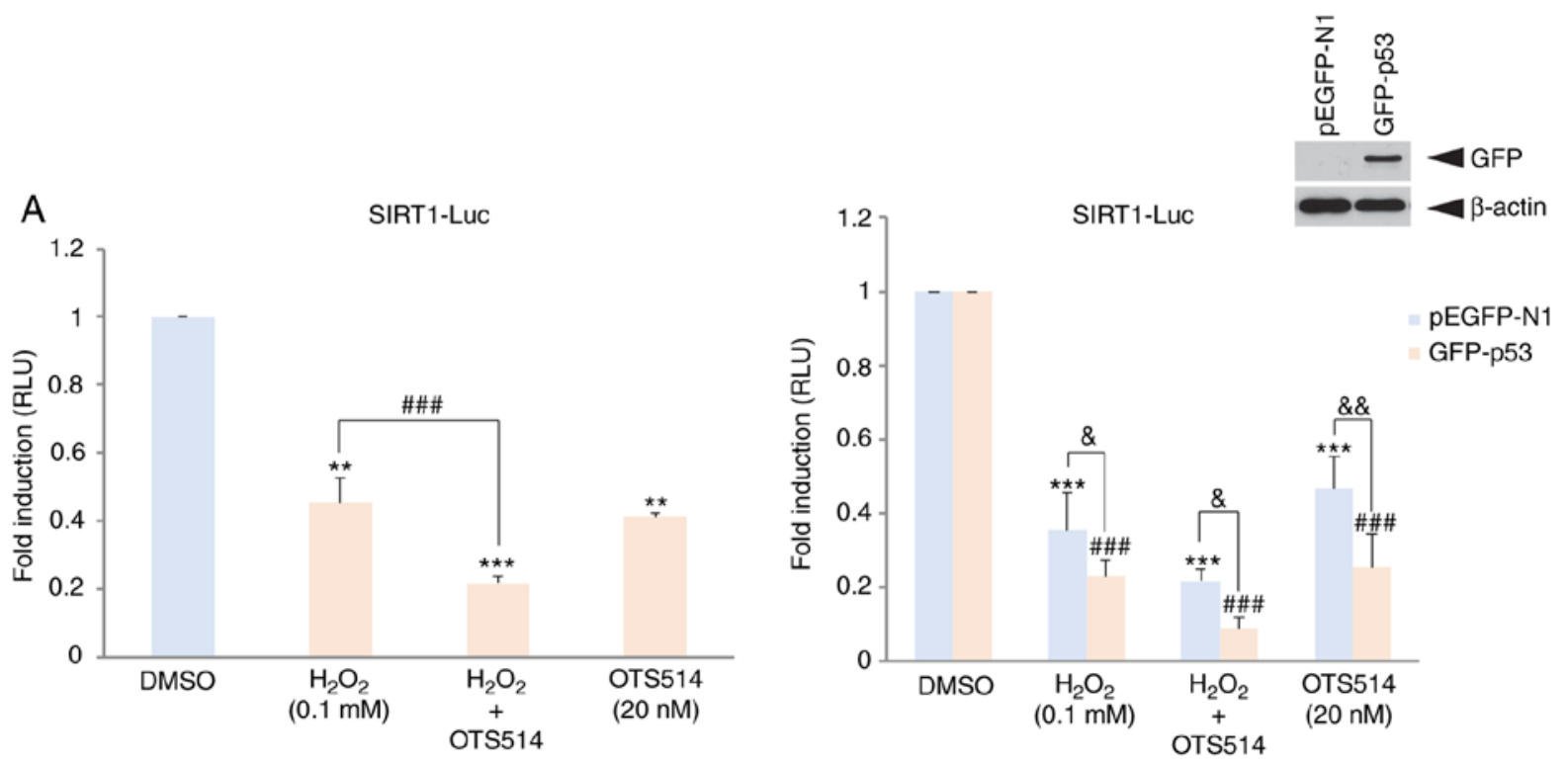

B
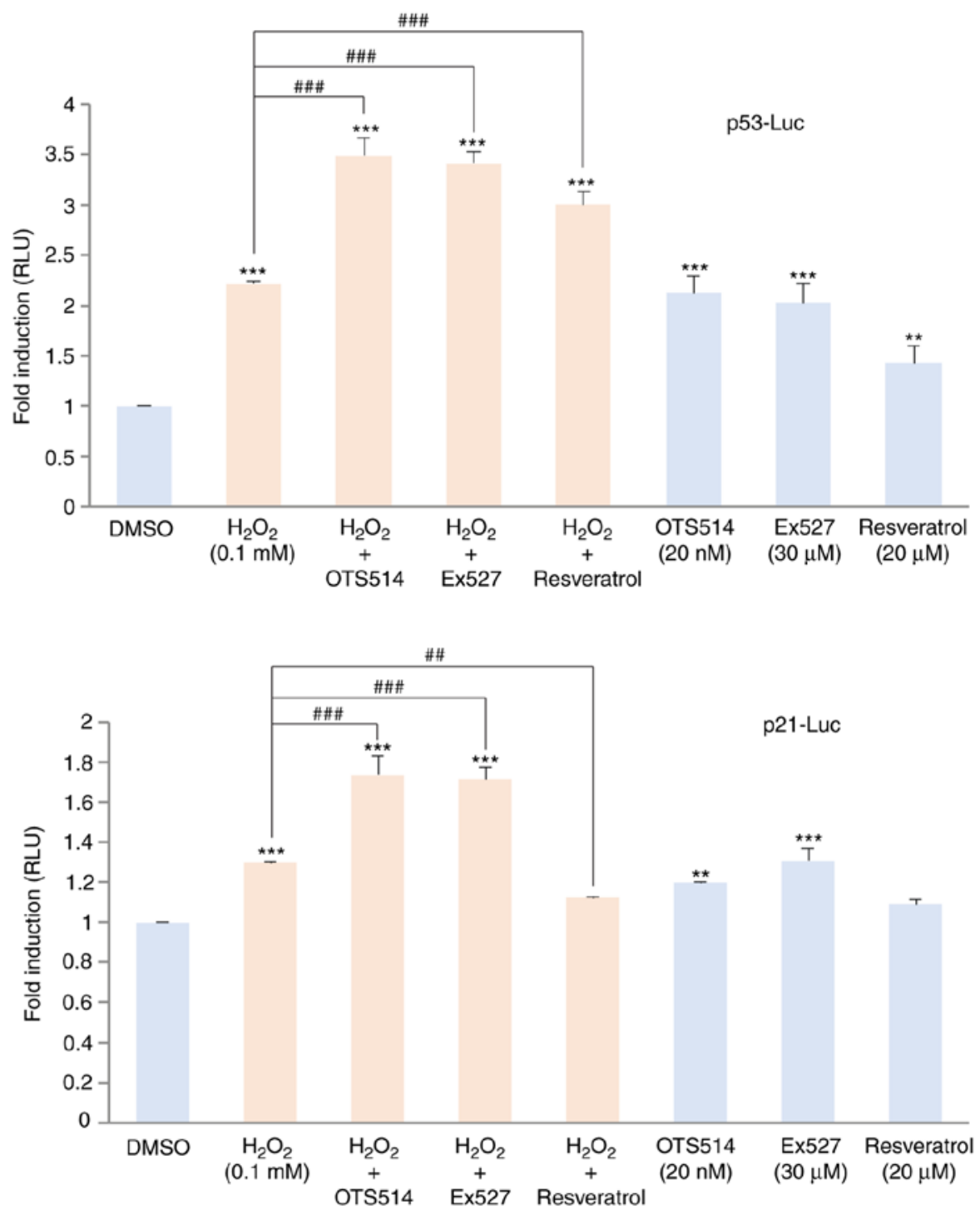

Figure 7. TOPK inhibition mitigates $\mathrm{H}_{2} \mathrm{O}_{2}$-downregulated SIRT1 transcriptional activity, but promotes p53 or p21 transcriptional activity upregulated by $\mathrm{H}_{2} \mathrm{O}_{2}$. (A) COV434 cells were transfected with SIRT1 promoter driven luciferase reporter construct (SIRT1-LUC) alone or SIRT1-LUC together with GFP-p53 or pEGFP-N1 plus $p R L-S V 40$ gene. At $24 \mathrm{~h}$ following transfection, cells were treated with DMSO, $\mathrm{H}_{2} \mathrm{O}_{2}, \mathrm{OTS}_{14}$ or $\mathrm{H}_{2} \mathrm{O}_{2}$ plus $\mathrm{OTS}_{14}$ for $24 \mathrm{~h}$. (B) COV434 cells were transfected with p53-luciferase ( $p 53-L U C)$ or p21-luciferase ( $p 21-L U C)$ plus $p R L-S V 40$ gene. At 24 h post-transfection, cells were incubated in combination of $\mathrm{H}_{2} \mathrm{O}_{2}$ with OTS514, EX527 or resveratrol for $24 \mathrm{~h}$. Firefly luciferase activity was estimated by normalization against Renilla luciferase activity. Relative luciferase unit (RLU) is indicated. ${ }^{* *} \mathrm{P}<0.01,{ }^{* * *} \mathrm{P}<0.001$ vs. DMSO. ${ }^{\# \#} \mathrm{P}<0.01,{ }^{\# \# \#} \mathrm{P}<0.001$ vs. H2O2. ${ }^{\text {} P}<0.05$, \& ${ }^{\&} \mathrm{P}<0.01$ (two-way ANOVA with Bonferroni's correction). 


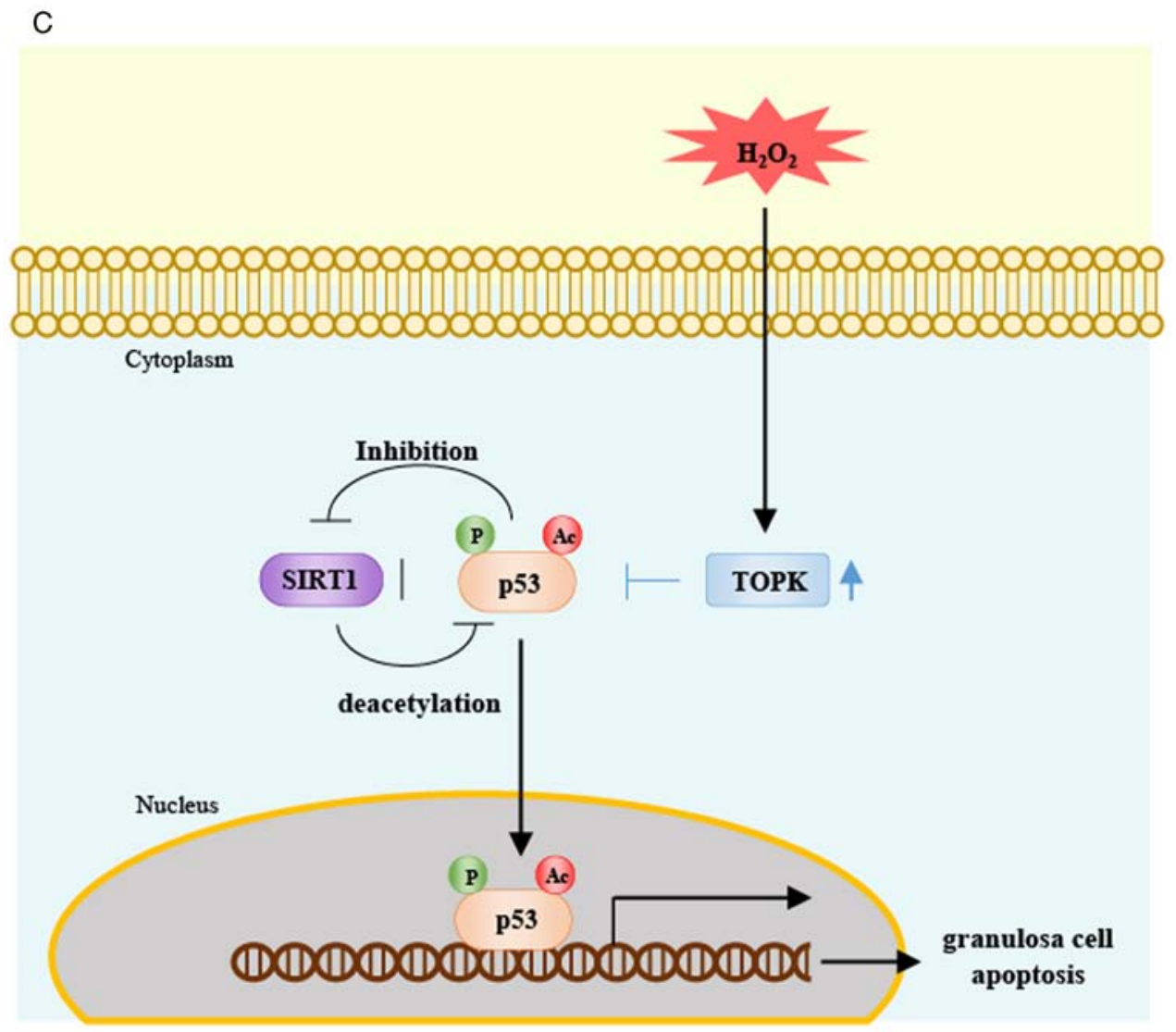

Figure 7. Continued. TOPK inhibition mitigates $\mathrm{H}_{2} \mathrm{O}_{2}$-downregulated SIRT1 transcriptional activity, but promotes p53 or p21 transcriptional activity upregulated by $\mathrm{H}_{2} \mathrm{O}_{2}$. (C) Schematic model for role of TOPK-p53-SIRT axis in regulation of granulosa cell apoptosis. TOPK is increased in response to $\mathrm{H}_{2} \mathrm{O}_{2}$, but TOPK downregulated by TOPK inhibitor OTS514 results in elevation of activity and expression of p53, which leads to the suppression of SIRT1 expression, thereby promoting p53-mediated granulosa cell apoptosis.

TOPK inhibition decreases the SIRT1 transcriptional level downregulated by $\mathrm{H}_{2} \mathrm{O}_{2}$, but increases the $\mathrm{H}_{2} \mathrm{O}_{2}$-induced p53 transcriptional level. It has been suggested that $\mathrm{p} 53$ negatively regulates SIRT1 expression. It has also been suggested that p53 negatively regulates SIRT1 expression (11). The present study thus examined the effect of TOPK inhibition on the SIRT1 or p53 transcriptional level, and the effect of p53 expression on the SIRT1 transcriptional level upon $\mathrm{H}_{2} \mathrm{O}_{2}$ stimulation. COV434 cells were transfected with SIRT1 or a p53 promoter-driven luciferase reporter construct. At $24 \mathrm{~h}$ following transfection, the cells were incubated with a combination of $\mathrm{H}_{2} \mathrm{O}_{2}$ or OTS514. The results indicated that stimulation of the COV434 cells with $\mathrm{H}_{2} \mathrm{O}_{2}$ resulted in a decrease in the SIRT1 transcriptional level and co-treatment with OTS514 promoted this decrease (Fig. 7A). On the other hand, co-treatment with OTS514 promoted the level of p53 or the p53 target, p21 transcriptional level induced by $\mathrm{H}_{2} \mathrm{O}_{2}$ (Fig. 7B). Notably, the expression of GFP-p53 diminished the SIRT1 transcriptional level downregulated by $\mathrm{H}_{2} \mathrm{O}_{2}$ (Fig. 7A). These findings demonstrate that upon $\mathrm{H}_{2} \mathrm{O}_{2}$ exposure, TOPK inhibition suppresses the SIRT1 transcriptional level and enhances the p53 transcriptional level, and that p53 negatively regulates SIRT1 expression. In addition, schematic model indicated that TOPK inhibition enhanced p53-mediated granulosa cell apoptosis through SIRT1 downregulation in response to $\mathrm{H}_{2} \mathrm{O}_{2}$ (Fig. 7C), suggesting the role of TOPK in the SIRT1/p53 regulatory axis.

\section{Discussion}

Granulosa cells are well known to be a class of cells that constitute a follicle for oocyte maturation. It has been proposed that granulosa cells and oocytes form gap junctions through connexins, which transfer low molecular weight molecules, such as cGMP, cAMP and calcium, and that granulosa cells transfer nutrients and regulatory factors for the growth and differentiation of oocytes (39-43). In addition, it seems that granulosa cells protect oocytes from oxidative stress involving ROS during follicle development. ROS have been reported to carry out functions that induce follicle rupture, and to regulate the expression of genes which induce oocyte maturation; however, accumulated ROS levels have been shown to cause oxidative stress that damages oocytes and granulosa cells (44-47). ROS mainly produced from the mitochondria cause mitochondrial damage to increase Bax expression, decrease Bcl-2 expression, and to release cytochrome $c$ that forms the apoptosome, leading to the activation of the caspase cascade $(48,49)$.

In this study, it was determined whether TOPK can affect oxidative stress-induced human granulosa cell apoptosis. It has been suggested that OTS514, a thieno[2,3-c]quinolone compound, strongly suppresses the growth of TOPK-positive cancer cells, including ovarian cancer, lung cancer or leukemia with low IC50 values ranging from 1.5 to $14 \mathrm{nM}$ (50-52). OTS514 was shown to inhibit TOPK expression as well as TOPK kinase 
activity. It has been suggested that OTS514 suppresses Forkhead box protein M1 (FOXM1) and FOXM1 transactivates the c-Myc promoter $(52,53)$. Furthermore, c-Myc has been shown to positively regulate TOPK expression (54). In addition, FOXM1 enhances cyclin B1 that phosphorylates TOPK on the Thr-9 residue (55). Collectively, it seems that OTS514 inhibits TOPK activity and expression by suppressing FOXM1 or c-Myc. Based on these reports, an inhibitor was employed in the presents study to suppress TOPK expression or activity. The inhibition of TOPK activity or expression by the TOPK inhibitor, OTS514, exacerbated $\mathrm{H}_{2} \mathrm{O}_{2}$-induced COV434 granulosa cell apoptosis, which is dependent on caspase signaling pathways. It was also found that ROS production was markedly increased by co-treatment with $\mathrm{H}_{2} \mathrm{O}_{2}$ and TOPK inhibitor than with $\mathrm{H}_{2} \mathrm{O}_{2}$ only in COV434 granulosa cells. consistent with these findings, it has been previously demonstrated that TOPK inhibits the accumulation of $\mathrm{H}_{2} \mathrm{O}_{2}$ in RPMI7951 melanoma cells (56), induces the expression of manganese superoxide dismutase (MnSOD), an essential antioxidant enzyme localized in the mitochondria, in PC12 cells (57), and induces the expression of Nrf2, an antioxidant molecule, to reduce ROS (58). Collectively, the present study provides evidence that TOPK negatively regulates oxidative stress-induced granulosa cell apoptosis, thereby positively contributing to follicular development.

It has been suggested that oxidative stress induces tumor suppressor p53 to increase the expression of p53 target proteins, including p21, Bax and PUMA $(9,59,60)$. In granulosa cells, oxidative stress has also been shown to result in PUMA expression, leading to the promotion of apoptosis through p53 induction (33). The findings of the presents study demonstrated that TOPK inhibition by OTS514 elevated the expression of total p53, acetylated p53 or the phosphorylated p53 level in granulosa cells. In addition, it was found that the inhibition of p53 degradation by Nutlin 3 accelerated $\mathrm{H}_{2} \mathrm{O}_{2}$-mediated granulosa cell apoptosis. It appears that the increase in the phosphorylated or acetylated p53 level, as well as the total p53 level contributed to the apoptosis. In agreement with these findings, it has been reported that TOPK binds to the p53 DNA binding domain, leading to the inhibition of expression of p53 and p53 target protein, p21, and thereby the induction of cell cycle arrest $(29,30)$. Moreover, it has been proposed that the phosphorylation of p53 at the Ser-15 residue decreases its interaction with Mdm2, but increases its interaction with $\mathrm{CBP} / \mathrm{p} 300$, thereby promoting p53 acetylation and activity $(61,62)$. It is well known that $\mathrm{p} 53$-mediated apoptosis is due to the p53 translocation into the mitochondria. The present study confirmed that p53 inhibition by Pifithrin- $\mu$, an inhibitor of p53 binding to the mitochondria alleviates granulosa cell apoptosis induced by $\mathrm{H}_{2} \mathrm{O}_{2}$ and OTS514. Previous studies have demonstrated that mitochondrial p53 accumulation promotes the opening of the mitochondrial permeability transition pore (MPTP), which is a protein channel for the regulation of mitochondrial membrane permeability (63-65). Mitochondrial p53 is known to induce Bak and Bax oligomerization and to suppress the anti-apoptotic activity of Bcl-xL and Bcl-2 $(63,66,67)$.

On the other hand, it has been suggested that p53 deacetylation is mostly caused by HDACs, but SIRT1 specifically deacetylates p53 at the K382 residue $(60,68,69)$. The present study found that the regulation of p53 acetylation by SIRT1 activator or inhibitor affected $\mathrm{H}_{2} \mathrm{O}_{2}$-induced granulosa cell apoptosis, and that $\mathrm{H}_{2} \mathrm{O}_{2}$-induced apoptosis was further decreased by resveratrol and Pifithrin- $\mu$, and increased by Ex527 and Nutlin 3. Furthermore, TOPK inhibition diminished SIRT1 transcriptional activity downregulated by $\mathrm{H}_{2} \mathrm{O}_{2}$ treatment and p53 expression promoted the inhibitory effect of TOPK, which may be due to an increase in p53 expression induced by TOPK inhibition. In agreement with these findings, previous studies have suggested that p53 inhibits SIRT1 transcription by directly binding to the SIRT1 promoter, and that TOPK functions as a suppressor for p53 $(11,30)$.

It has been suggested that SIRT1 binds to p53 and deacetylates the C-terminal $\mathrm{p} 53$ residue, Lys382, to negatively regulate the transcriptional activity of p53 $(70,71)$. In the present study, the SIRT1 activator, resveratrol, or the SIRT1 inhibitor, Ex527, decreased or increased $\mathrm{H}_{2} \mathrm{O}_{2}$-induced TOPK expression, respectively. Although research on the regulation of the TOPK promoter remains elusive, p53 may transcriptionally modulate TOPK expression (16). Therefore, these findings may be due to the change in the $\mathrm{H}_{2} \mathrm{O}_{2}$ induction of SIRT1-mediated p53 transactivation, activity regulating TOPK expression. Taken together, these findings provide evidence for a novel role of TOPK in the p53/SIRT1 regulatory axis that mediates granulosa cell apoptosis. Therefore, TOPK may be a novel target molecule for the improvement of follicular development or oocyte maturation.

\section{Acknowledgements}

The authors would like to thank the laboratory (Protein Expression Laboratory, Department of Biochemstry, Konyang University) members for their helpful discussion about this work.

\section{Funding}

The present study was supported by the National Research Foundation of Korea (NRF) grants funded by the Korea government (MSIP) (NRF-2019R1I1A3A01063191). The present study was also supported by the Priority Research Centers Program through the NRF funded by the MEST (NRF-2017R1A6A1A03015713).

\section{Availability of materials and data}

The data that support the findings of the present study are available from the corresponding author on reasonable request.

\section{Authors' contributions}

JHP and SAP conducted experiments, collected data, analyzed data and wrote the manuscript. YJL and NRJ performed experiments. JS provided some reagents and made suggestions during the performing of the experiments and data analysis. SMO designed and supervised the study. All authors read and approved the final manuscript.

\section{Ethics approval and consent to participate}

Not applicable. 


\section{Patient consent for publication}

Not applicable.

\section{Competing interests}

The authors declare that they have no competing interests.

\section{References}

1. Adeldust H, Zeinoaldini S, Kohram H, Amiri Roudbar M and Daliri Joupari M: In vitro maturation of ovine oocyte in a modified granulosa cells co-culture system and alpha-tocopherol supplementation: Effects on nuclear maturation and cleavage. J Anim Sci Technol 57: 27, 2015.

2. Tripathi A, Shrivastav TG and Chaube SK: An increase of granulosa cell apoptosis mediates aqueous neem (Azadirachta indica) leaf extract-induced oocyte apoptosis in rat. Int J Appl Basic Med Res 3: 27-36, 2013.

3. Devine PJ, Perreault SD and Luderer U: Roles of reactive oxygen species and antioxidants in ovarian toxicity. Biol Reprod 86: 27 , 2012.

4. Tatone C, Di Emidio G, Vitti M, Di Carlo M, Santini S, D'Alessandro AM, Falone S and Amicarelli F: Sirtuin functions in female fertility: Possible role in oxidative stress and aging. Oxid Med Cell Longev 2015: 659687, 2015.

5. Yang H, Yan B, Liao D, Huang S and Qiu Y: Acetylation of HDAC1 and degradation of SIRT1 form a positive feedback loop to regulate p53 acetylation during heat-shock stress. Cell Death Dis 6: e1747, 2015.

6. Han Y, Luo H, Wang H, Cai J and Zhang Y: SIRT1 induces resistance to apoptosis in human granulosa cells by activating the ERK pathway and inhibiting NF- $\mathrm{kB}$ signaling with anti-inflammatory functions. Apoptosis 22: 1260-1272, 2017.

7. Abdolvahabi Z, Nourbakhsh M, Hosseinkhani S, Hesari Z, Alipour M, Jafarzadeh M, Ghorbanhosseini SS, Seiri P, Yousefi Z, Yarahmadi S and Golpou P: MicroRNA-590-3P suppresses cell survival and triggers breast cancer cell apoptosis via targeting sirtuin-1 and deacetylation of p53. J Cell Biochem 120: 9356-9368, 2019.

8. Yu X, Zhang S, Zhao D, Zhang X, Xia C, Wang T, Zhang M, Liu T, Huang $\mathrm{W}$ and $\mathrm{Wu} \mathrm{B}$ : SIRT1 inhibits apoptosis in in vivo and in vitro models of spinal cord injury via microRNA-494. Int J Mol Med 43: 1758-1768, 2019.

9. Han MK, Song EK, Guo Y, Ou X, Mantel C and Broxmeyer HE: SIRT1 regulates apoptosis and Nanog expression in mouse embryonic stem cells by controlling p53 subcellular localization. Cell Stem Cell 2: 241-251,2008.

10. Kume S, Haneda M, Kanasaki K, Sugimoto T, Araki Si, Isono M, Isshiki K, Uzu T, Kashiwagi A and Koya D: Silent information regulator 2 (SIRT1) attenuates oxidative stress-induced mesangial cell apoptosis via p53 deacetylation. Free Radic Biol Med 40: 2175-2182, 2006.

11. Yuan F, Liu L, Lei Y and Tang P: P53 inhibits the upregulation of sirtuin 1 expression induced by c-Myc. Oncol Lett 14: 4396-4402, 2017.

12. Zlobec I, Molinari F, Kovac M, Bihl MP, Altermatt HJ, Diebold J, Frick H, Germer M, Horcic M, Montani M, et al: Prognostic and predictive value of TOPK stratified by KRAS and BRAF gene alterations in sporadic, hereditary and metastatic colorectal cancer patients. Br J Cancer 102: 151-161, 2010.

13. Zykova TA, Zhu F, Wang L, Li H, Bai R, Lim DY, Yao K, Bode AM and Dong Z: The T-LAK cell-originated protein kinase signal pathway promotes colorectal cancer metastasis. EBioMedicine 18: 73-82, 2017.

14. Su TC, Chen CY, Tsai WC, Hsu HT, Yen HH, Sung WW and Chen CJ: Cytoplasmic, nuclear, and total PBK/TOPK expression is associated with prognosis in colorectal cancer patients: A retrospective analysis based on immunohistochemistry stain of tissue microarrays. PLoS One 13: e0204866, 2018.

15. Shih MC, Chen JY, Wu YC, Jan YH, Yang BM, Lu PJ, Cheng HC, Huang MS, Yang CJ, Hsiao $M$ and Lai JM: TOPK/PBK promotes cell migration via modulation of the PI3K/PTEN/AKT pathway and is associated with poor prognosis in lung cancer. Oncogene 31: 2389-2400, 2012.
16. Lei B, Qi W, Zhao Y, Li Y, Liu S, Xu X, Zhi C, Wan L and Shen H: PBK/TOPK expression correlates with mutant p53 and affects patients' prognosis and cell proliferation and viability in lung adenocarcinoma. Hum Pathol 46: 217-224, 2015.

17. Ohashi T, Komatsu S, Ichikawa D, Miyamae M, Okajima W, Imamura T, Kiuchi J, Kosuga T, Konishi H, Shiozaki A, et al: Overexpression of PBK/TOPK relates to tumour malignant potential and poor outcome of gastric carcinoma. Br J Cancer 116: 218-226, 2017.

18. Sun H, Zhang L, Shi C, Hu P, Yan W, Wang Z, Duan Q, Lu F, Qin L, Lu T, et al: TOPK is highly expressed in circulating tumor cells, enabling metastasis of prostate cancer. Oncotarget 6: 12392-12404, 2015.

19. Pirovano G, Ashton TM, Herbert KJ, Bryant RJ, Verrill CL, Cerundolo L, Buffa FM, Prevo R, Harrap I, Ryan AJ, et al: TOPK modulates tumour-specific radiosensitivity and correlates with recurrence after prostate radiotherapy. Br J Cancer 117: 503-512, 2017.

20. Ikeda Y, Park JH, Miyamoto T, Takamatsu N, Kato T, Iwasa A, Okabe S, Imai Y, Fujiwara K, Nakamura Y, et al: T-LAK cell-originated protein kinase (TOPK) as a prognostic factor and a potential therapeutic target in ovarian cancer. Clin Cancer Res 22: 6110-6117, 2016.

21. Wang MY, Lin ZR, Cao Y, Zheng LS, Peng LX, Sun R, Meng DF, Xie P, Yang JP, Cao L, et al: PDZ binding kinase (PBK) is a theranostic target for nasopharyngeal carcinoma: Driving tumor growth via ROS signaling and correlating with patient survival. Oncotarget 7: 26604-26616, 2016.

22. Ohashi T, Komatsu S, Ichikawa D, Miyamae M, Okajima W, Imamura T, Kiuchi J, Nishibeppu K, Kosuga T, Konishi H, et al: Overexpression of PBK/TOPK contributes to tumor development and poor outcome of esophageal squamous cell carcinoma. Anticancer Res 36: 6457-6466, 2017.

23. Abe Y, Matsumoto S, Kito K and Ueda N: Cloning and expression of a novel MAPKK-like protein kinase, lymphokine- activated killer T-cell-originated protein kinase, specifically expressed in the testis and activated lymphoid cells. J Biol Chem 275: 21525-21531, 2000.

24. Matsumoto S, Abe Y, Fujibuchi T, Takeuchi T, Kito K, Ueda N, Shigemoto $\mathrm{K}$ and Gyo K: Characterization of a MAPKK-like protein kinase TOPK. Biochem Biophys Res Commun 325: 997-1004, 2004.

25. Zhu F, Zykova TA, Kang BS, Wang Z, Ebeling MC, Abe Y, Ma WY, Bode AM and Dong Z: Bidirectional signals transduced by TOPK-ERK interaction increase tumorigenesis of HCT116 colorectal cancer cells. Gastroenterology 133: 219-231, 2007.

26. Aksamitiene E, Kholodenko BN, Kolch W, Hoek JB and Kiyatkin A: PI3K/Akt-Sensitive MEK-independent compensatory circuit of ERK activation in ER-positive PI3K-mutant T47D breast cancer cells. Cell Signal 22: 1369-1378, 2010.

27. Oh SM, Zhu F, Cho YY, Ki WL, Bong SK, Kim HG, Zykova T, Bode AM and Dong Z: T-Lymphokine-activated killer cell-originated protein kinase functions as a positive regulator of c-Jun-NH2-kinase 1 signaling and $\mathrm{H}$-ras-induced cell transformation. Cancer Res 67: 5186-5194, 2007.

28. Seol MA, Park JH, Jeong JH, Lyu J, Han SY and Oh SM: Role of TOPK in lipopolysaccharide-induced breast cancer cell migration and invasion. Oncotarget 8: 40190-40203, 2017.

29. Nandi AK, Ford T, Fleksher D, Neuman B and Rapoport AP: Attenuation of DNA damage checkpoint by PBK, a novel mitotic kinase, involves protein-protein interaction with tumor suppressor p53. Biochem Biophy Res Commun 358: 181-188, 2007.

30. Hu F, Gartenhaus RB, Eichberg D, Liu Z, Fang HB and Rapoport AP: PBK/TOPK interacts with the DBD domain of tumor suppressor p53 and modulates expression of transcriptional targets including p21. Oncogene 29: 5464-5474, 2010.

31. Park JH, Yoon DS, Choi HJ, Hahm DH and Oh SM: Phosphorylation of $\mathrm{I} \kappa \mathrm{B} \alpha$ at serine 32 by T-lymphokine-activated killer cell-originated protein kinase is essential for chemoresistance against doxorubicin in cervical cancer cells. J Biol Chem 288: 3585-3593, 2013.

32. Weng Q, Liu Z, Li B, Liu K, Wu W and Liu H: Oxidative stress induces mouse follicular granulosa cells apoptosis via JNK/FoxOlpathway. PLoS One 11: e0167869, 2016.

33. Yang H, Xie Y, Yang D and Ren D: Oxidative stress-induced apoptosis in granulosa cells involves JNK, p53 and puma. Oncotarget 8: 25310-25322, 2017. 
34. Zhang M, Zhang Q, Hu Y, Xu L, Jiang Y, Zhang C, Ding L, Jiang R, Sun J, Sun H and Yan G: MiR-181a increases FoxO1 acetylation and promotes granulosa cell apoptosis via SIRT1 downregulation. Cell Death Dis 8: e3088, 2017.

35. Joel M, Mughal AA, Grieg Z, Murrell W, Palmero S, Mikkelsen B, Fjerdingstad HB, Sandberg CJ, Behnan J, Glover JC, et al: Targeting PBK/TOPK decreases growth and survival of glioma initiating cells in vitro and attenuates tumor growth in vivo. Mol Cancer 14: 121, 2015.

36. Kim DJ, Li Y, Reddy K, Lee MH, Kim MO, Cho YY, Lee SY, Kim JE, Bode AM and Dong Z: Novel TOPK inhibitor HI-TOPK-032 effectively suppresses colon cancer growth. Cancer Res 72: 3060-3068, 2012.

37. Xu M and Xu S: PBK/TOPK overexpression and survival in solid tumors: A PRISMA-compliant meta-analysis. Medicine (Baltimore) 98: e14766, 2019.

38. Keren-Tal I, Suh BS, Dantes A, Lindner S, Oren M and Amsterdam A: Involvement of 553 expression in cAMP-mediated apoptosis in immortalized granulosa cells. Exp Cell Res 218 283-295, 1995

39. Heller DT, Cahill DM and Schultz RM: Biochemical studies of mammalian oogenesis: Metabolic cooperativity between granulosa cells and growing mouse oocytes. Dev Biol 84: 455-464, 1981.

40. Brower PT and Schultz RM: Intercellular communication between granulosa cells and mouse oocytes: Existence and possible nutritional role during oocyte growth. Dev Biol 90: 144-153, 1982.

41. Bruzzone R, White TW and Paul DL: Connections with connexins: The molecular basis of direct intercellular signaling. Eur J Biochem 238: 1-27, 1996.

42. Kumar NM and Gilula NB: The gap junction communication channel. Cell 84: 381-388, 1996.

43. Grazul-Bilska AT, Reynolds LP and Redmer DA: Gap junctions in the ovaries. Biol Reprod 57: 947-957, 1997.

44. Yang HW, Hwang KJ, Kwon HC, Kim HS, Choi KW and Oh KS: Detection of reactive oxygen species (ROS) and apoptosis in human fragmented embryos. Hum Reprod 13: 998-1002, 1998.

45. Hensley K, Robinson KA, Gabbita SP, Salsman S and Floyd RA Reactive oxygen species, cell signaling, and cell injury. Free Radic Biol Med 28: 1456-1462, 2000

46. Dröge W: Free radicals in the physiological control of cell function. Physiol Rev 82: 47-95, 2002.

47. Goud AP, Goud PT, Diamond MP, Gonik B and Abu-Soud HM Reactive oxygen species and oocyte aging: Role of superoxide hydrogen peroxide, and hypochlorous acid. Free Radic Biol Med 44: 1295-1304, 2008.

48. Li D, Ueta E, Kimura T, Yamamoto T and Osaki T: Reactive oxygen species (ROS) control the expression of Bcl-2 family proteins by regulating their phosphorylation and ubiquitination. Cancer Sci 95: 644-650, 2004.

49. Alarifi S, Ali H, Alkahtani S and Alessia MS: Regulation of apoptosis through bcl-2/bax proteins expression and DNA damage by nano-sized gadolinium oxide. Int J Nanomedicine 12: 4541-4551, 2017

50. Alachkar H, Mutonga M, Malnassy G, Park JH, Fulton N, Woods A, Meng L, Kline J, Raca G, Odenike O, et al: T-LAK cell-originated protein kinase presents a novel therapeutic target in FLT3-ITD mutated acute myeloid leukemia. Oncotarget 6 : 33410-33425, 2015.

51. Matsuo Y, Park JH, Miyamoto T, Yamamoto S, Hisada S, Alachkar $\mathrm{H}$ and Nakamura Y: TOPK inhibitor induces complete tumor regression in xenograft models of human cancer through inhibition of cytokinesis. Sci Transl Med 6: 259ra145, 2014

52. Park JH, Inoue H, Kato T, Zewde M, Miyamoto T, Matsuo Y, Salgia R and Nakamura Y: TOPK (T-LAK cell-originated protein kinase) inhibitor exhibits growth suppressive effect on small cell lung cancer. Cancer Sci 108: 488-496, 2017.
53. Wierstra I and Alves J: FOXM1c transactivates the human c-myc promoter directly via the two TATA boxes P1 and P2. FEBS J 273: 4645-4667, 2006

54. Hu F, Gartenhaus RB, Zhao XF, Fang HB, Minkove S, Poss DE and Rapoport AP: C-Myc and E2F1 drive PBK/TOPK expression in high-grade malignant lymphomas. Leukemia Res 37: 447-454, 2013 .

55. Leung TW, Lin SS, Tsang AC, Tong CS, Ching JC, Leung WY, Gimlich R, Wong GG and Yao KM: Over-expression of foxM1 stimulates cyclin B1 expression. FEBS Lett 507: 59-66, 2001.

56. Zykova TA, Zhu F, Vakorina TI, Zhang J, Higgins LA, Urusova DV, Bode AM and Dong Z: T-LAK cell-originated protein kinase (TOPK) phosphorylation of prx1 at ser-32 prevents UVB-induced apoptosis in RPMI7951 melanoma cells through the regulation of Prx1 peroxidase activity. J Biol Chem 285: 29138-29146, 2010.

57. Zhao H, Wang R, Tao Z, Gao L, Yan F, Gao Z, Liu X, Ji X and Luo Y: Ischemic postconditioning relieves cerebral ischemia and reperfusion injury through activating T-LAK cell-originated protein kinase/protein kinase b pathway in rats. Stroke 45: 2417-2424, 2014.

58. Liu Y, Liu H, Cao H, Song B, Zhang W and Zhang W: PBK/TOPK mediates promyelocyte proliferation via Nrf2-regulated cell cycle progression and apoptosis. Oncol Rep 34: 3288-3296, 2015.

59. Hsieh TC, Juan G, Darzynkiewicz Z and Wu JM: Resveratrol increases nitric oxide synthase, induces accumulation of p53 and p21(WAF1/CIP1), and suppresses cultured bovine pulmonary artery endothelial cell proliferation by perturbing progression through S and G2. Cancer Res 59: 2596-2601, 1999 .

60. Luo J, Nikolaev AY, Imai S, Chen D, Su F, Shiloh A, Guarente L and Gu W: Negative control of p53 by Sir2alpha promotes cell survival under stress. Cell 107: 137-148, 2001.

61. Shieh SY, Ikeda M, Taya Y and Prives C: DNA damage-induced phosphorylation of p53 alleviates inhibition by MDM2. Cell 91: 325-334, 1997.

62. Lambert PF, Kashanchi F, Radonovich MF, Shiekhattar R and Brady JN: Phosphorylation of p53 serine 15 increases interaction with CBP. J Biol Chem 273: 33048-33053, 1998.

63. Marchenko ND and Moll UM: Mitochondrial death functions of p53. Mol Cell Oncol 1: e955995, 2014.

64. Chen LJ, Gao YQ, Li XJ, Shen DH and Sun FY: Melatonin protects against MPTP/MPP+ -induced mitochondrial DNA oxidative damage in vivo and in vitro. J Pineal Res 39: 34-42, 2005.

65. Yu W, Zhang X, Liu J, Wang X, Li S, Liu R, Liao N, Zhang T and Hai C: Cyclosporine A suppressed glucose oxidase induced P53 mitochondrial translocation and hepatic cell apoptosis through blocking mitochondrial permeability transition. Int J Biol Sci 12: 198-209, 2016.

66. Wolff S, Erster S, Palacios G and Moll UM: P53's mitochondrial translocation and MOMP action is independent of puma and bax and severely disrupts mitochondrial membrane integrity. Cell Res 18: 733-744, 2008.

67. Sykes SM, Mellert HS, Holbert MA, Li K, Marmorstein R, Lane WS and McMahon SB: Acetylation of the p53 DNA-binding domain regulates apoptosis induction. Mol Cell 24: 841-851, 2006.

68. Brooks $\mathrm{CL}$ and $\mathrm{Gu} \mathrm{W}$ : The impact of acetylation and deacetylation on the p53 pathway. Protein Cell 2: 456-462, 2011.

69. Islam S, Abiko Y, Uehara O and Chiba I: Sirtuin 1 and oral cancer. Oncol Lett 17: 729-738, 2019.

70. Ong AL and Ramasamy TS: Role of sirtuin1-p53 regulatory axis in aging, cancer and cellular reprogramming. Ageing Res Rev 43: 64-80, 2018

71. van Leeuwen I and Lain S: Sirtuins and p53. Adv Cancer Res 102: 171-195, 2009. 